\title{
A Nationwide Survey on Clinical Curricula and Practica in Speech-Language Pathology Educational Programs in Korea
}

\author{
Jaeock Kim ${ }^{\mathrm{a}}$, Seong Hee Choi ${ }^{\mathrm{b}}$, HyangHee Kim ${ }^{\mathrm{c}, \mathrm{d}}$, Son A Chang, ${ }^{\mathrm{e}}$, Hyo Jung Kim ${ }^{\mathrm{f}}$, BoMyung Hwang, Hyun Rin Park \\ Hee-June Park ${ }^{\mathrm{i}}$ \\ ${ }^{a}$ Division of Speech Pathology Education, Graduate School of Education, Kangnam University, Yongin, Korea \\ ${ }^{b}$ Department of Audiology \& Speech-Language Pathology, College of Bio and Medical Sciences, Daegu Catholic University, Gyeongsan, Korea \\ ${ }^{c}$ Graduate Program in Speech and Language Pathology, Yonsei University, Seoul, Korea \\ ${ }^{d}$ Department of Rehabilitation Medicine and Research Institute of Rehabilitation Medicine, Yonsei University College of Medicine, Seoul, Korea \\ 'Department of Otorhinolaryngology-Head and Neck Surgery, Seoul National University Hospital, Seoul, Korea \\ ${ }^{f}$ Department of Speech-Language Pathology, College of Health and Welfare, Kosin University, Busan, Korea \\ ${ }^{8}$ Department of Speech-Language Pathology, School of Health Science, Honam University, Gwangju, Korea \\ ${ }^{h}$ Department of Speech-Language Therapy, College of Health, Welfare E Education, Gwangiu University, Gwangju, Korea \\ iDepartment of Speech \& Language Therapy, Choonhae College of Health Sciences, Ulsan, Korea
}

Correspondence: Seong Hee Choi, PhD

Department of Audiology and Speech-Language Pathology, Institute of Biomimetic Sensory Control \& Catholic Hearing Voice Speech Center, Daegu Catholic University, 13-13 Hayang-ro, Hayang-eup, Gyeongsan 38430, Korea

Tel: $+82-53-850-2532$

Fax: +82-53-359-6780

E-mail: shgrace@cu.ac.kr

Received: April 23, 2018

Revised: May 27, 2018

Accepted: May 27, 2018

This work was supported by funding for the Accreditation Project of the Korean Association of Speech-Language Pathologists (KSLP) and was partly presented at the 2017 Annual Meeting of the Korean Council of Academic Programs of Communication Disorders (KoCAPCD) held on November 4, 2017
Objectives: The number of educational programs in speech-language pathology/therapy in Korea continues to increase, and has reached a total of 87 programs in 50 universities. However, no nationwide survey on the clinical curricula and practica of the educational programs has been carried out. Methods: A questionnaire consisting of items on clinicbased courseworks, clinical practicum, and clinical educational setting was distributed, and a total of 57 (10 community college, 19 undergraduate, 28 graduate) programs participated in the survey. Results: Although most of programs ran core clinical courses required for obtaining the national license, various credits of clinical courses, clinical hours, and practical area, and clinical environments were documented. Most graduate school programs permitted students with speech-language pathology backgrounds or speech-language pathologist (SLP) licenses to be exempt from clinical coursework and practicums. Language development in preschool or school-age children was the most predominant practice area in most of the programs. Supervision of clinical activities in all three types of educational settings was provided by licensed faculty or supervisors. Conclusion: In order to ensure the consistency of qualified clinical training or education across the speech-language pathology programs, standard clinical guidelines regarding education training contents or environment should be established. Moreover, diverse clinical education and training should be provided to enhance the SLP profession and to facilitate the development of the field of communication sciences and disorders in the upcoming years.

Keywords: Clinical curriculum, Clinical practicum, Speech-language pathology program 언어재활사(speech-language pathologist, SLP)는 생애 전반에 걸쳐 나타날 수 있는 다양한 의사소통의 문제를 진단하고 평가하 며 치료 중재할 뿐 아니라 언어치료 업무를 발전시켜 나가기 위한 교육과 연구 등의 제반 업무를 담당하는 전문가이다(Kim et al., 2014; Pyo, 2017a). 언어재활사의 전문성을 함양하기 위해서는 우선
언어재활사를 양성하는 교육기관에서 학생들에게 전공과 관련된 이론적 지식과 함께 언어재활현장에서 적용할 수 있는 임상실습 훈련이 절대적으로 필요하다. 언어재활 임상실습은 언어치료 전공 학생이 언어재활 관련 이론 교과목들의 지식과 기술을 종합하여 의사소통장애 대상자에게 진단, 평가, 중재 그리고 부모상담 등을 
직접 적용함으로써 언어재활에 대한 실제적 경험을 얻을 수 있도록 하는 교육과정이다(Kim \& Shin, 2015; Yoon \& Kim, 2013).

2012년 8월부터 시행된 장애인복지법 시행규칙 별표6의 2에 언 어재활사 국가자격 제도의 수립과 전문적인 언어재활사 양성을 위 해 임상실습과 관련된 언어재활관찰 및 언어진단실습과 언어재활 실습을 필수교과목으로 지정하고 있다(National Law Information Center, 2018). 임상실습은 임상관찰과 진단 및 치료실습의 두 영역 으로 나누어져 있다. 언어재활관찰은 30 시간을 수행해야 하고, 진 단 및 치료 실습은 총 90 시간 이상을 실시하여야 하며 전체 시간의 절반 이상을 교내에서 실시해야 한다는 규정이 있다. 그러나 이 법 령에서는 임상실습시간을 수업시간으로 명시하였고, 임상실습 장 소도 교내라고만 제시되어 있기 때문에 다양한 해석이 가능하다. 즉, 임상실습시간이 실제 치료회기 시간을 의미하는 것인지 혹은 실습 시수를 의미하는지 등의 실습시간에 대한 정의, 그리고 교내 실습장소의 범위와 실습형태 등에 대한 가이드라인이 명확하게 제 시되어 있지 않기 때문에 언어재활사 양성 교육기관에 따라 운영 방식이 다양하게 나타날 수 있다는 것이다. 선행연구에 따르면, 대 부분의 양성 교육기관들이 법령에서 규정하고 있는 임상실습 과목 을 전공필수 교과목의 형식으로 운영함으로써, 운영 형식은 유사 하지만 실습시간, 실습장소 또는 실습방법 등의 실습내용은 각 교 육기관별로 매우 다양하다고 보고하였다(Kim \& Shin, 2015). 특히 국내 언어재활사 양성 교육기관은 3년제 전문대학, 4년제 대학교, 대학원(일반대학원, 특수대학원)으로 학제의 범위가 다양하기 때 문에 학제별로 임상실습 운영 형식이 다르게 나타날 수 있다. 25개 대학원을 대상으로 임상실습 과목 운영의 기초 현황을 살펴본 선 행연구(Pyo, 2017a, 2017b)에 따르면, 각 대학원별로 임상실습관련 교과목과 학점, 임상실습 장소, 임상실습 감독자 등을 다양하게 운 영하고 있을 뿐만 아니라 2 급 자격증을 이미 소지한 학생들에게는 임상실습을 실시하지 않고 연구중심으로만 교과과정을 편성하고 있는 대학원들도 있다고 보고하였다. 이와같이 학제나 대학별로 임 상실습 형태가 다양하게 진행될 것이라는 것은 예측이 가능하다.

미국의 경우, 미국언어청각협회(American Speech-LanguageHearing Association, ASHA)에서 인정하는 대학원 과정에서 언어 병리학 석사 또는 박사학위를 취득하고, 최소 25 시간의 임상관찰, 그리고 실습 감독자의 감독하에 375 시간의 임상실습과정을 거친 후, SLP Praxis 자격시험에 합격해야만 말-언어병리학의 임상실무 수행능력 자격증(Certificate of Clinical Competence in SpeechLanguage Pathology, CCC-SLP)이 주어진다(www.asha.org). 교과 목 개설과 관련하여 임상관찰은 4년제 대학교 과정에 개설되어 있 지만, 임상 자격증 취득을 위한 언어진단실습과 언어재활실습은
대학원 교과과정에 개설되어 있고, 다양한 영역에서 엄격한 실습 시수를 적용하고 있으며, 졸업 후 1 년간 전일제로 일하면서 임상수 련과정을 거쳐야 자격증을 취득할 수 있다. 이후에도 추가적으로 다양한 이수과정을 통해 3 년마다 최소 30 시간의 전문 지식 교육을 지속적으로 받아야만 자격증을 유지할 수 있어 평생학습을 필요 로 한다. 아울러, 동일 영어권인 미국, 영국, 호주, 캐나다는 언어치 료사 자격증을 상호 인정하고 허용하도록 법안이 마련되어 있다 (Boswell, 2004). 이외에 공립학교 언어치료 자격증은 교육부에서 발급하는 자격증으로, 일반적으로 기초 및 심화과정을 요구하며, 학교 환경에서의 임상수련과정과 이후 국가 혹은 주별 자격시험을 합격하면 말-언어장애 학생의 교사 자격증을 받을 수 있으며, 학교 SLP로 활동하게 된다. 학교 SLP는 최소한 학사 학위를 필요로 하지 만, 많은 주들이 석사학위를 그 출발 요건으로 규정하고 있거나 채 용 후 몇 년 이내에 석사학위를 취득할 것을 요구한다.

국내의 임상실습 형태에 대한 학제별, 대학별 기초적인 실태 조 사로는 임상실습 감독자와 졸업생에게 임상실습 교육모형에 대해 교과목 편제, 실습 운영 내용, 감독자와 실습생의 관계, 실습환경 등 에 관한 적정성이나 만족도를 조사한 연구(Kim \& Lee, 2009)와 학 과인증제를 위한 기초 자료를 수집하기 위해 언어치료 프로그램을 운영하는 23 개 대학의 전반적인 교육환경을 살펴본 연구(Kwon et al., 2010)가 있다. 이 연구들은 언어재활사의 국가자격화가 이루어 지기 이전 민간 자격증 취득을 위한 임상실습 과정의 기초자료에 대한 내용을 포함하고 있다. 이후 언어재활사 국가자격 도입 후 임 상실습에 관한 대학교육의 실태를 파악한 연구로는 25 개 대학원만 을 대상으로 교과목 개설과 운영 및 임상실습실에 관한 내용을 조 사한 연구(Pyo, 2017a, 2017b)와 실습생들을 대상으로 실습만족도 (Hwang, Choi, Kim, \& Lee, 2012; Kim \& Shin, 2015; Yoon \& Kim, 2013)나 자기효능감(Lee \& Park, 2016; Lee, Park, \& Park, 2015)을 조사한 연구가 있으나, 임상실습과 관련된 규정이나 가이드라인을 제시한 연구는 매우 부족한 실정이다.

임상실습은 미래 언어재활사가 되고자 하는 전공학생들에게는 수업을 통해 수동적으로 습득한 지식을 실제 임상현장에서 능동 적으로 표현함으로써 의사소통장애를 평가, 진단, 중재 및 상담과 관련된 양질의 지식과 경험을 축적할 수 있는 매우 중요한 과정이 다. 또한 언어재활 전공학생에게 제공되는 임상실습은 이들이 졸업 한 후에 임상실습의 경험을 임상현장에서 바로 적용할 수 있어야 하므로 양적으로나 질적으로 높은 수준의 임상실습이 제공되어야 할 것이다.

앞서 언급한 바와 같이 언어재활사 양성을 위한 임상실습으로는 '언어재활관찰', '언어진단실습, '언어재활실습' 이라는 3 과목의 필 
수교과목을 일정 장소에서 일정 시간을 이수하여야 하고, 이와 더 불어 '언어재활현장실무’라는 과목에서 전 의사소통장애 영역의 이론과 실무를 종합적으로 학습해야 하는데, 학제별로 이 과목들 을 이수하는 학기나 학년, 실습 시수, 심화실습의 이수 여부 등이 다를 수 있기 때문에 실제로 각 학제나 교육기관별로 어떻게 운영 이 되고 있는지 운영내용을 살펴볼 필요가 있다. 또한 이러한 교과 목들을 이수하는 과정에서 전문 자격증을 소지한 임상감독자의 감독과 지도 하에 임상실습이 이루어져야 하는데, 임상감독자의 자격과 역할 및 능력에 따라 학생 치료사가 쌓아가는 임상경험의 양과 질이 현저하게 다를 수 있다. 따라서 각 교육기관별로 임상감 독자의 자격이나 임상경력 등도 함께 살펴볼 필요가 있다. 이와 더 불어 임상실습 장소나 실습하는 의사소통장애 영역에 따라 학생 치료사가 경험할 수 있는 의사소통장애의 범위가 다를 수 있으며, 실습현장에서 제공하는 실습시설과 기자재에 따라 임상실무를 수 행할 수 있는 능력의 차이가 나타날 수 있으므로 각 학제와 교육기 관들이 이들을 어떻게 제공하고 구비하고 있는지 또한 파악할 필 요가 있다.

이에, 본 연구는 전문학사(Associate degree), 학사(Bachelor's degree), 석사 및 박사(Master's \& Doctoral degrees)의 각 학위 과정을 운영하는 3 년제 전문대학, 4 년제 대학교, 대학원의 다양한 학제 및 다양한 교육기관별로 임상실습이 어떻게 운영되고 있는지 설문조 사를 통해 파악하고자 하였다. 특히 임상실습 교과과정 현황, 임상 실습 운영 현황, 실습시설과 기자재 등의 임상실습 현황 등에 관한 실태를 살펴보고, 이를 통해 국내 언어치료사를 양성하는 교육기 관의 임상실습과 관련된 규정이나 가이드라인을 제공하는 기초 자 료로 사용되고자 하였다. 본 연구를 통해 학제별 임상실습 현황 및 공통점과 차이점을 좀 더 정확하게 파악하고, 각 학제들은 이를 기 반으로 보다 나은 임상실습 환경을 제공함으로써 언어재활 임상현 장의 발전에 기여할 수 있을 것으로 본다.

\section{연구방법}

\section{연구대상}

2018년 3월 현재, 전국언어치료학과협의회(이하 전언협)에 등록 된 언어치료(재활) 프로그램이 개설되어 있는 총 50 개교, 즉 12 개 전문대학교(이하 전문대), 24 개 4년제 대학교(이하 대학교; 사이버 대와 산업대 제외), 14 개 대학원(이하 대학원)에서 개설되고 있는 87 개 교육과정 프로그램들(12개 전문대의 12 개 교육과정, 24 개 대 학교의 24 개 교육과정, 38 개 대학원의 38 개 석사과정과 13 개 박사 과정) 중에서 2018년에 신설된 3개 교육과정 프로그램을 제외한 48
Table 1. Number of speech-language pathology academic programs surveyed

\begin{tabular}{lcccc}
\hline & $\begin{array}{c}\text { Associate } \\
\text { degree }\end{array}$ & $\begin{array}{c}\text { Bachelor's } \\
\text { degree }\end{array}$ & $\begin{array}{c}\text { Master's } \\
\text { degree }\end{array}$ & Total \\
\hline Survey invitation & 12 & 24 & 38 & 84 \\
Respondents & 10 & 19 & 28 & 57 \\
\hline
\end{tabular}

개 대학교의 총 84 개 프로그램을 대상으로 설문지를 배포하였다. 이들 중에서 36 개 대학교의 57 개 프로그램(10개 전문대, 19 개 대학 교, 28개 대학원)이 설문에 회신하여, 교육과정 프로그램 수의 회 신율은 $67.9 \%$ 이었다. 설문을 조사한 프로그램 수와 설문에 응답한 프로그램 수의 현황은 Table 1에 제시하였다.

\section{설문 도구}

설문지는 국내 언어치료 프로그램의 전국 단위 임상실습 운영 현 황에 대한 기초 자료 수집을 목적으로 작성되었다. 설문지 제작을 위해 전언협에서 사단법인 한국언어재활사협회 자문위원단의 자 문을 받아 설문지 초안을 작성하였으며, 국내 언어치료학과 인증제 를 위한 기초연구(Kwon et al., 2010)와 언어치료 임상실습 관련 교 재(Lee et al., 2010), 언어치료 임상실습 교육 모형 개발 및 적용(Kim \& Lee, 2009)의 기초연구, 언어치료학과 대학원 석사과정의 언어재 활관찰실습과 언어진단 및 언어재활실습 현황 연구(Pyo, 2017a, 2017b)의 기초 자료, ASHA에서 명시하는 교육 내용 및 절차 등을 참고하여 설문지는 크게 "임상실습 교과과정” "임상실습 운영”, 그리고 “임상실습 환경”의 세 가지 영역으로 구성된 예비문항을 제 작하였다. 내용타당도를 검증하기 위하여 언어치료 관련 양 학회 (한국언어청각임상학회, 한국언어치료학회)의 각 2-3명으로 구성 된 자문위원단을 통해 2 차례의 자문회의와 수 차례의 회의를 거쳐 예비문항의 내용타당도를 검증하였고, 검토되어 강조된 내용을 바 탕으로 내용을 수정하여 최종 설문지를 제작하였다.

\section{임상실습 교과과정}

언어치료전공 학생들은 학과에서 개설된 교과과정을 이수하고 일정 시간 이상의 임상관찰과 진단 및 치료 실습을 거친 후 학위를 취득하고 보건복지부에서 주관하는 국가시험을 통과하면 언어재 활사 자격증을 얻게 된다. 특히, 언어재활사라는 전문적 직업에 부 합하기 위해서는 이론 중심의 교육과정과는 별도로 임상실습 교육 과정 개설이 매우 중요하다. 각 교육기관에서 제공되는 임상교육 과 정이 질 높은 임상교육을 제공하기에 적절한지 판단하기 위해서 전 체 교육과정과는 별도로 임상실습 과목을 분리하여 심도 있게 다 루는 것은 매우 중요하다. 따라서, 주요 임상실습 교과목 이수 후 언 
어재활사자격을 받기에 적정한 지 확인하기 위해서 2017년에 개설 된 각 교육기관의 임상실습 교과과정과 교과목 정보, 수강인원과 교수진 정보를 조사하였다.

또한, 졸업 후 학생들이 언어치료 임상현장에서 취업하면, 다양 한 임상현장에서 평가, 진단,치료, 상담 등의 업무를 담당하게 되는 데 교육기관에서 제공하는 언어치료 실습이 현장에서 필요로 하는 지식을 제공하는 것은 매우 중요하다. 따라서, 이러한 관점에서 국 가시험 시행과 더불어 2012년부터 개설된 언어재활현장실무 교과 목이 각 교육 기관마다 어떻게 운영되고 있는지를 검토하였다.

이에 “임상실습 교과과정”은 실습관련 4개 교과목(언어재활관 찰, 언어진단실습, 언어재활실습, 언어재활현장실무)의 '교과과정 및 교과목 정보'에 관한 5 문항과 ‘수강인원 및 교수진 정보'에 관한 5 문항으로 구성하였다.

\section{임상실습 운영 및 임상실습 환경}

임상실습의 운영 방식은 졸업 후 양질의 언어치료서비스를 제공 할 수 있는 언어재활사의 배출과 직접적인 연관이 있으므로 임상실 습교육 운영 실태를 파악하는 것은 매우 중요하다. 교내 임상실습 지침, 사전 교육, 임상실습 서식, 임상감독 지침과 같은 감독자 및 실 습자 지침서 구비 여부를 조사하였고, 교수진 환경으로 임상실습 감독 형태(직접, 간접), 보고서 관련 피드백, 임상감독 소요시간, 실 습자 환경으로 사례발표, 강의평가/만족도 조사, 심화/현장 실습 운 영(실습 기관, 의사소통장애 실습영역), 실습비용 지불 체계(임상실 습비 여부, 실습비 부담 주체)을 파악하였으며, 현행 실습 제도에 대 한 실습 변화 방향을 조사하였다. 또한, 언어재활사라는 전문적 직 업에 부합하기 위해서는 상담, 평가, 재활 및 보장구 등을 다룰 수 있는 능력을 갖추어야 하는데, 최근 국가차원의 관심과 지원이 증 가하고 있으며, 모든 의사소통장애 영역에 공통적으로 사용될 수 있는 보장구와 관련된 보완대체의사소통(alternative \& augmentative communication, AAC)의 진단 및 평가와 실습을 진행하고 있 는지 추가적으로 파악하였다.

각 교육기관에서 양질의 임상교육과 훈련을 위한 적절한 실습교 육 환경의 조건이 충족되어 있는지 조사하였다. 이러한 실습 환경의 적정성을 조사하기 위하여 교내 자체 내 실습센터 구비 여부 및 실 습실 규모(면적, 치료실 개수와 형태)와 실습 장비, 검사도구 및 실습 기자재, 실습 기자재 확보를 조사에 포함하였다. 이 외에 기타 실습 센터 전담 인원(임상교수/실습조교), 학교 기업 현황을 조사하였다.

이에 “임상실습 운영”은 ‘교내 기본 임상실습'에 관한 10 문항, '실 습 장소, 영역 및 시간'에 관한 4 문항, '심화/현장실습'에 관한 3 문항, '임상실습비 운용'에 관한 4문항, '임상실습 면제'에 관한 3 문항,
'AAC 임상실습’에 관한 5문항의 총 29문항으로 구성하였다. 다만, '임상실습 면제'에 관한 문항들은 대학교에서 전공하고 대학원에 진학한 경우에 임상실습이 면제되는 경우가 많다는 선행연구(Pyo, 2017b)에 근거하여 대학원 과정에만 질문하였다. "임상실습 환경” 은 '실습실'과 관련된 12 문항과 '검사도구 및 기자재'에 관한 9문항 의 총 21 문항으로 구성하였다. 또한 '임상실습 운영 시 어려운 점'과 '운영 개선을 위한 제언'에 관한 2개의 주관식 문항을 추가로 포함 시켰다(Appendix 1).

\section{자료수집}

설문에 앞서 각 프로그램의 학과장과 교수들에게 설문의 목적 과 취지를 설명하였고, 각 설문은 자발적으로 참여하도록 하였다. 2017년 10월부터 2018년 2월까지 총 36개 대학교의 57개 교육과정 프로그램이 본 설문에 참여하였으며, 설문 작성은 각 프로그램의 학과장들에게 이메일을 통해 설문지를 배부한 후, 학과장이 엑셀 에 직접 작성한 자료를 이메일을 통해 회신 받았다. 기간 내에 응답 하지 않은 프로그램장에게는 유선을 통해 설문에 응답해 줄 것을 다시 요청하였고, 회신된 설문지에서 일부 누락된 문항들에 대해서 는 학과장에게 유선상으로 해당 문항들을 직접 묻고 답변한 것을 연구자가 기록하였다.

\section{자료분석}

자료의 분석은 IBM SPSS Statistics 24.0 (IBM, Armonk, NY, USA)으로 빈도분석을 실시하여 각 문항의 응답 빈도수와 백분율 및 평균과 표준편차를 산출하였다. 세 학제 유형에 따른 빈도의 차 이는 Fisher의 정확도 검정을 사용하여 비교하였고, 평균의 차이는 일원분산분석으로 비교하였으며, 이때 세 학제 유형 간 평균의 유 의한 차이가 있는 경우에는 Bonferroni 사후검정을 실시하였다. 유 의수준은 .05 였다.

\section{연구결과}

\section{임상실습 교과과정}

교육과정에 임상실습 교과목이 적절하게 개설되어 있는지를 조 사하기 위해 전체 교육과정 중 임상실습 교과과정 및 교과목 정보, 임상실습 교과목의 수강인원과 교수진 정보를 살펴보았다. 언어재 활관찰, 언어진단실습, 언어재활현장실무 교과목이 개설된 프로그 램은 전체 57 개 중 43 개( $75 \%$; 전문대 10 개, 대학교 19 개, 대학원 14 개)였는데, 특히 전문대와 대학교는 각각 $100 \%$ 의 교육과정에서 '언 어재활관찰'과 '언어진단실습' 교과목이 개설되어 있는 반면, 대학 
원의 경우에는 $50 \%$ ( 14 개)에서만 개설되었다. '언어재활실습' 교과 목이 개설된 프로그램은 총 44 개(77\%; 전문대 10 개, 대학교 19 개, 대학원 15 개)로서, 전문대와 대학교에서는 $100 \%$, 대학원에서는 $52 \%$ 가 개설되고 있다.

\section{교과과정 및 교과목 정보}

임상실습 교과목의 학점과 시수는 학교마다 다양하였다. 언어재 활관찰의 학점과 시수는 Table 2 와 같으며, 학점의 경우에는 전체 43 개 프로그램 중 1 학점이 1 개(2.3\%), 2 학점이 11 개( $25.6 \%), 3$ 학점 이 27개(62.8\%), 4학점이 3개(7.0\%), 6학점이 1개(2.3\%)였다. 언어재 활관찰 학점은 세 학제 간에 유의한 차이가 있었는데 $\left(\chi^{2}=12.914\right.$, $p=.030$ ), 전문대와 대학교는 3 학점이 가장 많았고, 대학원은 2 학점 이 가장 많았다. 언어재활관찰의 시수는 전체 43 개 프로그램 중 1 시수가 1개(2.3\%) 2시수는 8개(18.6\%) 3시수는 16개(37.2\%), 4시수 는 14 개(32.6\%), 5 시수는 1 개(2.3\%), 6시수는 3 개(7.0\%)였고, 학제 간 언어재활관찰 시수는 유의한 차이를 보였으며 $\left(\chi^{2}=18.069, p=.012\right)$, 전문대는 3 시수와 4 시수, 대학교는 4 시수, 대학원은 2 시수가 가장 많았다.

언어재활관찰의 학점과 시수가 일치하는지를 살펴본 결과, 일치 하는 경우는 30 개(69.8\%; 전문대 6 개, 대학교 10 개, 대학원 14 개)였
고, 불일치하는 경우는 13 개( $30.2 \%$; 전문대 4 개, 대학교 9개)였다. 이들은 학제 간에 유의한 차이를 보였으며 $\left(\chi^{2}=10.396, p=.005\right)$, 전 문대와 대학교는 일치와 불일치(학점에 비해 시수가 높음)의 비율 이 유사한 반면, 대학원은 모든 학교가 일치하였다(Figure 2).

언어진단실습은 과목이 서로 다른 학기에 걸쳐 2-3번 독립적으 로 개설된 경우(예: 언어진단실습 I \& II, 언어진단임상기기실습, 언 어진단심화실습 등) 이들을 합산하여 학점을 계산하였다. 그 결과 (Table 3), 전체 43 개 프로그램 중 2 학점은 17 개(39.5\%), 3 학점은 17 개(39.5\%), 4 학점은 4 개(9.37\%), 5학점은 1 개(4.7\%), 6학점은 2 개 (4.7\%), 7 학점은 1 개(2.3\%), 8 학점은 1 개(4.7\%)였다. 언어진단실습의 학점은 학제 간에 유의한 차이가 없었고 세 학제 모두 2-3학점이 많 았다. 언어진단실습 시수는 전체 43 개 프로그램 중 2시수가 11 개 (25.6\%), 3시수는 10개(23.3\%), 4시수가 13개(30.2\%), 5시수는 1개 (2.3\%), 6 시수는 5개(11.6\%), 8 시수는 1개(2.3\%), 10시수는 총 1개 (2.3\%), 14시수는 1개(2.3\%)였으며, 학제 간에 유의한 차이는 없었 고, 세 학제 모두 전체적으로 2-4시수가 많았다.

언어진단실습의 학점과 시수가 일치하는지를 살펴본 결과, 일치 하는 경우가 25개(58.1\%; 전문대 5개, 대학교 7개, 대학원 13개)였고, 불일치하는 경우가 18 개(41.9\%; 전문대 5 , 대학교 12 , 대학원 1 개)였 으며, 학제 간에 유의한 차이가 있었는데 $\left(\chi^{2}=11.302, p=.003\right)$, 전

Table 2. Credits and credit hours of clinical observation course

\begin{tabular}{|c|c|c|c|c|c|c|c|c|}
\hline \multirow{2}{*}{ Clinical observation } & \multicolumn{2}{|c|}{ Associate degree $(\mathrm{N}=10)$} & \multicolumn{2}{|c|}{ Bachelor's degree $(\mathrm{N}=19)$} & \multicolumn{2}{|c|}{ Master's degree ( $N=14)$} & \multicolumn{2}{|c|}{ Total } \\
\hline & Credit & Credit hour & Credit & Credit hour & Credit & Credit hour & Credit & Credit hour \\
\hline 1 & 0 & 0 & 0 & 0 & 1 & 1 & 1 & 1 \\
\hline 2 & 1 & 0 & 3 & 1 & 7 & 7 & 11 & 8 \\
\hline 3 & 8 & 5 & 15 & 7 & 4 & 4 & 27 & 16 \\
\hline 4 & 1 & 5 & 1 & 8 & 1 & 1 & 3 & 14 \\
\hline 5 & 0 & 0 & 0 & 1 & 0 & 0 & 0 & 1 \\
\hline 6 & 0 & 0 & 0 & 2 & 1 & 1 & 1 & 3 \\
\hline
\end{tabular}

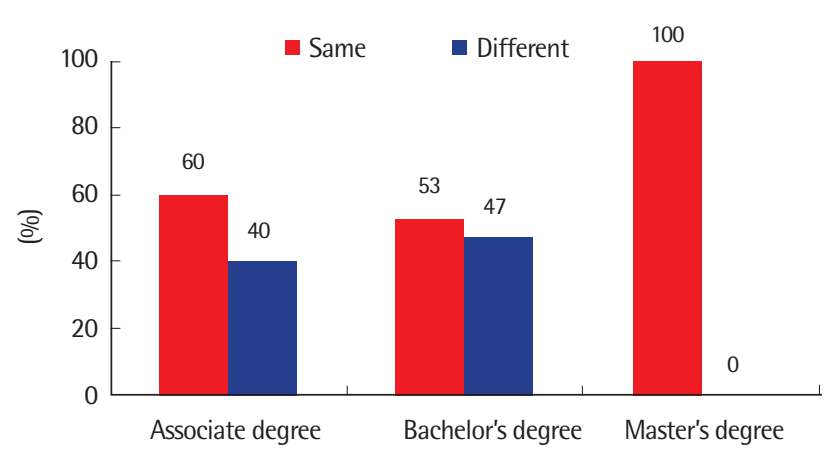

Figure 1. Difference between credits and credit hours of clinical observation course.

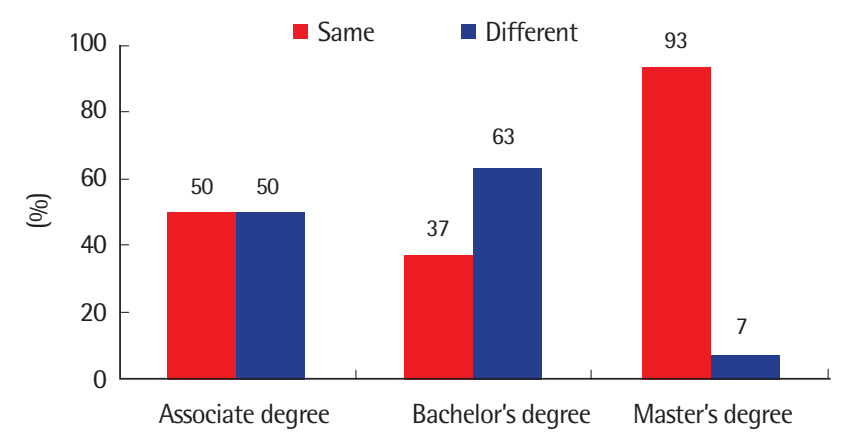

Figure 2. Difference between credits and credit hours of clinical evaluation course. 
Jaeock Kim, et al. • Clinical Curricula \& Practica in Speech-Language Pathology Programs

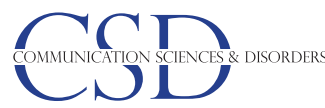

Table 3. Credits and credit hours of clinical evaluation course

\begin{tabular}{|c|c|c|c|c|c|c|c|c|}
\hline \multirow{2}{*}{ Clinical evaluation } & \multicolumn{2}{|c|}{ Associate degree $(\mathrm{N}=10)$} & \multicolumn{2}{|c|}{ Bachelor's degree $(\mathrm{N}=19)$} & \multicolumn{2}{|c|}{ Master's degree $(\mathrm{N}=14)$} & \multicolumn{2}{|c|}{ Total } \\
\hline & Credit & Credit hour & Credit & Credit hour & Credit & Credit hour & Credit & Credit hour \\
\hline 2 & 3 & 2 & 8 & 3 & 6 & 6 & 17 & 11 \\
\hline 3 & 6 & 3 & 8 & 5 & 3 & 2 & 17 & 10 \\
\hline 4 & 0 & 4 & 1 & 6 & 3 & 3 & 4 & 13 \\
\hline 5 & 1 & 0 & 0 & 1 & 0 & 0 & 1 & 1 \\
\hline 6 & 0 & 0 & 0 & 2 & 2 & 3 & 2 & 5 \\
\hline 7 & 0 & 0 & 1 & 0 & 0 & 0 & 1 & 0 \\
\hline 8 & 0 & 0 & 1 & 1 & 0 & 0 & 1 & 1 \\
\hline 10 & 0 & 1 & 0 & 0 & 0 & 0 & 0 & 1 \\
\hline 14 & 0 & 0 & 0 & 1 & 0 & 0 & 0 & 1 \\
\hline
\end{tabular}

Table 4. Credits and credit hours of clinical practicum course

\begin{tabular}{|c|c|c|c|c|c|c|c|c|}
\hline \multirow{2}{*}{ Clinical practicum } & \multicolumn{2}{|c|}{ Associate degree $(\mathrm{N}=10)$} & \multicolumn{2}{|c|}{ Bachelor's degree $(N=19)$} & \multicolumn{2}{|c|}{ Master's degree $(\mathrm{N}=15)$} & \multicolumn{2}{|c|}{ Total } \\
\hline & Credit & Credit hour & Credit & Credit hour & Credit & Credit hour & Credit & Credit hour \\
\hline 2 & 1 & 0 & 3 & 0 & 9 & 9 & 13 & 9 \\
\hline 3 & 7 & 2 & 7 & 2 & 3 & 3 & 17 & 7 \\
\hline 4 & 0 & 4 & 3 & 5 & 1 & 1 & 5 & 11 \\
\hline 5 & 1 & 0 & 0 & 1 & 0 & 0 & 1 & 1 \\
\hline 6 & 1 & 3 & 4 & 6 & 1 & 1 & 6 & 10 \\
\hline 8 & 0 & 0 & 2 & 1 & 0 & 0 & 2 & 1 \\
\hline 9 & 0 & 0 & 0 & 2 & 0 & 0 & 0 & 2 \\
\hline 10 & 0 & 1 & 0 & 1 & 0 & 0 & 0 & 2 \\
\hline 11 & 0 & 0 & 0 & 1 & 0 & 0 & 0 & 1 \\
\hline
\end{tabular}

문대는 학점과 시수가 일치와 불일치인 경우가 동일한 반면, 대학교 는 학점에 비해 시수가 많은 경우가 더 많았고, 대학원은 대다수가 일치하였다(Figure 1).

언어재활실습의 학점은 서로 다른 교과목의 형태로 독립적으로 개설된 경우(예: 언어재활실습 I \& II, 임상재활기기실습, 언어재활 심화실습, 현장실습 등) 이를 합산하였으며, 사례연구와 같이 직접 적인 실습과목이 아닌 경우는 학점에서 제외하였다. 그 결과 Table 4 와 같이, 전체 44 개 프로그램 중 2 학점은 13 개(29.5\%), 3학점은 17 개(38.6\%), 4 학점은 5 개(11.4\%), 5 학점은 1 개(2.3\%), 6학점은 6 개 (13.6\%), 8학점은 2개(4.5\%)였다. 언어재활실습의 학점은 학제 간에 유의한 차이를 보였는데 $\left(\chi^{2}=16.489, p=.026\right)$, 전문대와 대학교는 3 학점이 가장 많았고, 대학원은 2 학점이 가장 많았다. 언어재활실습 의 시수는 전체 44 개 프로그램 중 2시수가 9개(20.9\%), 3시수는 7 개(15.9\%), 4 시수는 11 개(25.0\%), 5시수는 1 개(2.3\%), 6시수는 총 10 개(22.7\%), 8 시수는 1 개(2.3\%), 9시수는 2개(4.5\%), 10 시수는 2 개 (4.5\%), 11 시수가 2 개(4.5\%)로 전체 중에 4 시수가 가장 많았다. 언어 재활실습 시수는 학제 간에 유의한 차이를 보였으며 $\left(\chi^{2}=27.595\right.$,

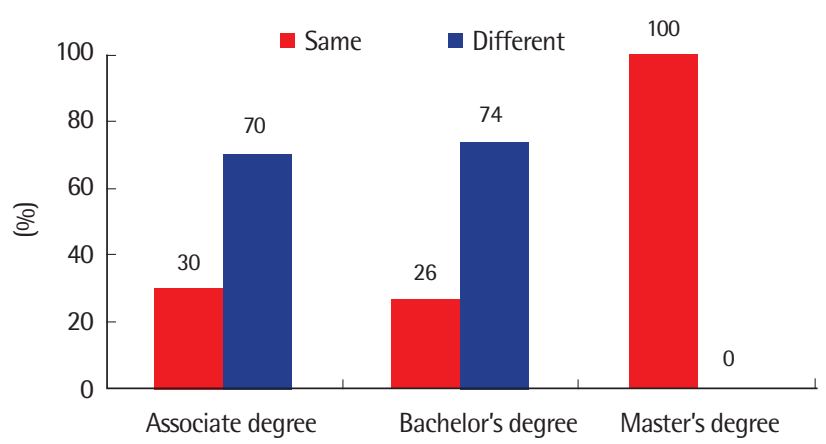

Figure 3. Difference between credits and credit hours of clinical practicum course.

$p=.002)$, 전문대는 4 시수, 대학교는 6시수, 대학원은 2 시수가 가장 많았다.

언어재활실습의 학점과 시수의 일치와 불일치를 살펴본 결과, 일 치하는 경우는 44 개 중 23개(52.3\%; 전문대, 3 개, 대학교 5개, 대학 원 15 개)였고, 불일치 경우가 21 개(47.7\%; 전문대 7 개, 대학교 14 개, 대학원 0 개)였다. 이는 학제 간에 유의한차이를 보였는데 $\left(\chi^{2}=23.294\right.$, 
$p<.001)$, 전문대와 대학교는 학점에 비해 시수가 높은 곳이 더 많은 반면, 대학원은 모두 학점과 시수가 일치하였다(Figure 3).

언어재활현장실무의 학점과 시수는 Table 5에 제시되었다. 학점 은 전체 44 개 프로그램 중 1 학점은 3 개(7.0\%)였으며, 2 학점은 16 개 (34.9\%), 3학점은 25개(58.1\%)로 3학점이 가장 많았고, 전문대와 대 학교는 3 학점이 가장 많았으며, 대학원은 2 학점이 많았으나 학제 간에 언어재활현장실무 학점은 유의한 차이는 없었다. 언어재활현 장실무 시수는 전체 44 개 프로그램 중 1시수가 3개(7.0\%), 2시수가 14 개(30.2\%), 3시수가 12 개(27.9\%), 4시수가 11 개(25.6\%), 5 시수는 1 개(2.3\%), 6시수는 3 개(7.0\%)였다. 언어재활현장실무 시수는 학제 간에 유의한 차이를 보였는데 $\left(\chi^{2}=16.636, p=.027\right)$, 전문대는 3 시 수, 대학교는 4 시수, 대학원은 2 시수가 가장 많았다.

언어재활현장실무의 학점과 시수의 일치 및 불일치를 살펴본 결 과, 44 개 프로그램 중 29개(65.9\%; 전문대 8개, 대학교 10개, 대학원 11 개)가 일치하였고, 15 개(34.1\%; 전문대 2개, 대학교 9개, 대학원 4 개)가 불일치하였으며, 학제 간의 유의한 차이는 없었다.
또한 언어치료학과 교육기관의 전체 교육과정 중 개설된 실습 교 과목의 중요도를 파악하기 위하여 교과목의 성격으로 전공/교양 과 필수/선택 여부 및 이론/실습 여부를 조사하였다. 그 결과는 Table 6 과 같이 언어재활관찰 교과목은 개설된 총 43 개 프로그램 중 전공필수가 20개(46.5\%), 전공선택이 23개(53.5\%)로 학제 간에 전 공필수와 전공선택의 유의한 차이는 없었다. 언어진단실습은 전공 필수로 17 개(39.5\%), 전공선택으로 26 개(60.5\%)가 개설되었고, 학 제 간에 유의한 차이를 보였는데 $\left(\chi^{2}=6.171, p=.041\right)$, 전문대와 대 학교는 전공선택이 많았고, 대학원은 전공필수가 더 많았다. 언어 재활실습은 개설된 44 개 프로그램 중에서 전공필수가 21 개(47.7\%), 전공선택이 23개(52.3\%)였다. 이는 학제 간에 유의한 차이를 보였 는데 $\left(\chi^{2}=9.635, p=.014\right)$, 전문대가 전공선택과 전공필수의 비율이 동일하였고, 대학교는 전공선택이 많았으며, 대학원은 전공필수가 더 많았다. 언어재활현장실무는 전공필수가 21 개(48.8\%), 전공선 택은 22개(51.2\%)였고, 학제 간에 전공필수와 전공선택의 유의한 차이가 없었다.

Table 5. Credits and credit hours of clinical field studies course

\begin{tabular}{|c|c|c|c|c|c|c|c|c|}
\hline \multirow{2}{*}{ Clinical field studies } & \multicolumn{2}{|c|}{ Associate degree $(\mathrm{N}=10)$} & \multicolumn{2}{|c|}{ Bachelor's degree ( $N=19)$} & \multicolumn{2}{|c|}{ Master's degree $(\mathrm{N}=15)$} & \multicolumn{2}{|c|}{ Total } \\
\hline & Credit & Credit hour & Credit & Credit hour & Credit & Credit hour & Credit & Credit hour \\
\hline 1 & 1 & 1 & 1 & 1 & 1 & 1 & 3 & 3 \\
\hline 2 & 1 & 1 & 6 & 5 & 9 & 8 & 16 & 14 \\
\hline 3 & 8 & 6 & 12 & 4 & 5 & 2 & 25 & 12 \\
\hline 4 & 0 & 0 & 0 & 7 & 0 & 4 & 0 & 11 \\
\hline 5 & 0 & 0 & 0 & 1 & 0 & 0 & 0 & 1 \\
\hline 6 & 0 & 2 & 0 & 1 & 0 & 0 & 0 & 3 \\
\hline
\end{tabular}

Table 6. Course type (required or optional) of clinical courses

\begin{tabular}{|c|c|c|c|c|c|c|c|c|}
\hline & \multicolumn{2}{|c|}{ Associate degree } & \multicolumn{2}{|c|}{ Bachelor's degree } & \multicolumn{2}{|c|}{ Master's degree } & \multicolumn{2}{|c|}{ Total } \\
\hline & $\mathrm{R}$ & 0 & $\mathrm{R}$ & 0 & $\mathrm{R}$ & 0 & $\mathrm{R}$ & 0 \\
\hline Clinical observation & 6 & 4 & 5 & 14 & 9 & 5 & 20 & 23 \\
\hline Clinical evaluation & 4 & 6 & 3 & 15 & 10 & 5 & 17 & 26 \\
\hline Clinical practicum & 5 & 5 & 5 & 14 & 11 & 3 & 21 & 23 \\
\hline Clinical field studies & 5 & 5 & 9 & 11 & 7 & 6 & 21 & 22 \\
\hline
\end{tabular}

$\mathrm{R}=$ required course; 0 = optional course.

Table 7. Course type (theory- or practice-oriented) of clinical courses

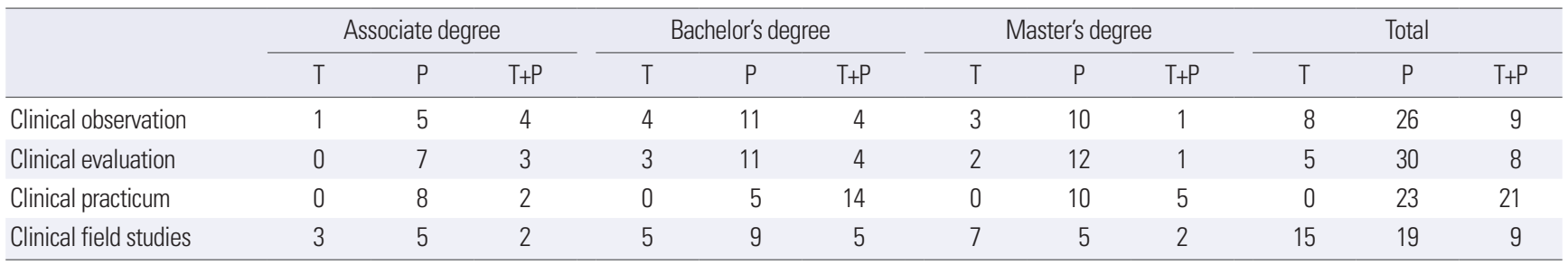

$\mathrm{T}=$ theory-oriented; $\mathrm{P}=$ practice-oriented; $\mathrm{T}+\mathrm{P}=$ theory and practice combined. 
임상실습 교과목 운영 형태를 살펴보면(Table 7), 언어재활관찰 의 수업방식은 이론으로만 실시하는 경우가 8 개(18.6\%), 실습만 하 는 경우 26개(60.5\%), 이론과 실습을 병행하는 경우는 9개(20.9\%) 로 대부분 실습 위주로 운영하였고, 학제 간에는 유의한 차이가 없 이 실습을 위주로 하는 경우가 많았다. 언어진단실습은 이론만 하 는 경우가 5 개(11.6\%), 실습만 하는 경우가 30개(69.8\%), 이론과 실 습을 병행하는 경우가 8 개(18.6\%)였으며, 실습 위주로 이루어지는 경우가 대부분으로 학제 간에 유의한 차이가 없었다. 언어재활실 습은 실습만 하는 경우가 23 개(52.3\%), 이론과 실습을 병행하는 경 우는 21 개(47.7\%)였다. 이는 학제 간에 유의한 차이를 보였는데 $\left(\chi^{2}=\right.$ $11.057, p=.006$ ), 전문대와 대학원은 실습을 위주로 하고, 대학교는 이론과 실습을 병행하는 경우가 많았다(Figure 4). 언어재활현장 실무는 이론만 하는 경우는 15 개(34.8\%), 실습만 하는 경우는 19개 (44.2\%), 이론과 실습을 병행하는 경우는 9개(20.9\%)였고, 학제 간 에 유의한 차이가 없이 이론만 하는 경우와 실습만 하는 프로그램 의 수가 유사하였다.

임상실습 교과목 수강 전 선수과목 여부는 Table 8과 같다. 언어 재활관찰 수강 전 선수과목이 있는 경우가 13 개(30.2\%)였고, 없는 경우가 30개(69.8\%)로 대부분 선수과목이 없었으며, 특히 대학교 와 대학원이 선수과목이 없는 경우가 유의하게 많았다 $\left(\chi^{2}=11.771\right.$, $p=.041)$. 언어진단실습수강 전 선수과목이 있는 경우가 25 개(58.1\%) 였고, 없는 경우가 18 개(41.8\%)로 전문대와 대학교는 선수과목이

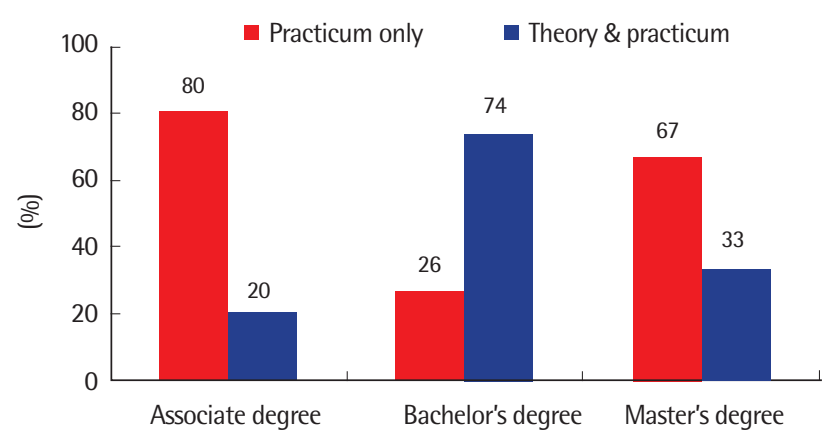

Figure 4. Course type of clinical practicum course.
있는 경우가 많은 반면, 대학원은 선수과목이 없는 경우가 많았고, 이는 통계적으로 유의한 차이를 보였다 $\left(\chi^{2}=21.519, p<.001\right)$. 언어 재활실습 수강 전 선수과목이 있는 경우가 37 개(84.1\%)였고, 없는 경우가 7개(15.9\%)였고, 학제 간에 유의한 차이는 있었으나 $\left(\chi^{2}=\right.$ $15.361, p=.003)$ 세 학제 대부분 선수 과목이 있었다. 언어재활현장 실무 수강 전 선수과목이 있는 경우가 12 개(27.9\%)였고, 없는 경우 가 31 개(72.1\%)였고, 학제 간에 유의한 차이는 없었으나 모든 학제 가 언어재활현장실무 수강 전 선수과목이 없는 경우가 많았다.

\section{수강인원과 교수진 정보}

실습지도의 질적 관리를 위해 실습교과목의 운영 방식으로 수강 인원 및 담당 교수진을 조사하였다.

언어재활관찰의 담당교수 1 인당 수강인원은 Table 9 와 같다. 10 명 미만이 10개(23.3\%), 10-19명은 6개(14.0\%), 20-29명은 11개(25.6\%), $30-39$ 은 12 개(27.9), 40-49명은 3개(7.0\%), 50명 이상은 1개(2.3\%)였 고, 전문대는 20-29명이, 대학교는 30-39명이, 대학원은 10 명 미만 이 유의하게 가장 많았다 $\left(\chi^{2}=30.914, p<.001\right)$.

언어진단실습의 담당교수 1 인당 수강인원은 Table 10 과 같다. 10 명 미만이 8개(18.6\%), 10-19명은 10개(23.3\%), 20-29명은 17개(39.5\%), 30-39명은 8개(18.6\%)였고, 전문대는 10-19명이, 대학교는 20-29명 이, 대학원은 10 명 미만과 20-29명이 가장 많았으며, 이러한 차이는 통계적으로 유의하였다 $\left(\chi^{2}=15.674, p=.008\right)$.

Table 9. Number of students per clinical supervisor in clinical observation course

\begin{tabular}{lrccr}
\hline & $\begin{array}{c}\text { Associate } \\
\text { degree }\end{array}$ & $\begin{array}{c}\text { Bachelor's } \\
\text { degree }\end{array}$ & $\begin{array}{c}\text { Master's } \\
\text { degree }\end{array}$ & Total \\
\hline $\begin{array}{l}\text { Number of students per supervisor } \\
<10\end{array}$ & 0 & 1 & 9 & 10 \\
$10-19$ & 3 & 0 & 3 & 6 \\
$20-29$ & 5 & 6 & 0 & 11 \\
$30-39$ & 2 & 8 & 2 & 12 \\
$40-49$ & 0 & 3 & 0 & 3 \\
$\geq 50$ & 0 & 1 & 0 & 1 \\
Sum & 10 & 19 & 14 & 43 \\
\hline
\end{tabular}

Table 8. Prerequisite courses for clinical courses

\begin{tabular}{|c|c|c|c|c|c|c|c|c|}
\hline & \multicolumn{2}{|c|}{ Associate degree } & \multicolumn{2}{|c|}{ Bachelor's degree } & \multicolumn{2}{|c|}{ Master's degree } & \multicolumn{2}{|c|}{ Total } \\
\hline & Yes & No & Yes & No & Yes & No & Yes & No \\
\hline Clinical observation & 4 & 6 & 7 & 12 & 2 & 12 & 13 & 30 \\
\hline Clinical evaluation & 9 & 1 & 12 & 6 & 4 & 11 & 25 & 18 \\
\hline Clinical practicum & 9 & 1 & 13 & 6 & 15 & 0 & 37 & 7 \\
\hline Clinical field studies & 2 & 8 & 5 & 14 & 5 & 9 & 12 & 31 \\
\hline
\end{tabular}


Table 10. Number of students per clinical supervisor in clinical evaluation course

\begin{tabular}{lrccr}
\hline & $\begin{array}{c}\text { Associate } \\
\text { degree }\end{array}$ & $\begin{array}{c}\text { Bachelor's } \\
\text { degree }\end{array}$ & $\begin{array}{c}\text { Master's } \\
\text { degree }\end{array}$ & Total \\
\hline Number of students per supervisor & & & \\
$<10$ & 0 & 3 & 5 & 8 \\
$10-19$ & 5 & 1 & 4 & 10 \\
$20-29$ & 2 & 10 & 5 & 17 \\
$30-39$ & 3 & 5 & 0 & 8 \\
Sum & 10 & 19 & 14 & 43 \\
\hline
\end{tabular}

Table 11. Number of students per clinical supervisor in clinical practicum course

\begin{tabular}{lcccc}
\hline & $\begin{array}{c}\text { Associate } \\
\text { degree }\end{array}$ & $\begin{array}{c}\text { Bachelor's } \\
\text { degree }\end{array}$ & $\begin{array}{c}\text { Master's } \\
\text { degree }\end{array}$ & Total \\
\hline $\begin{array}{l}\text { Number of students per supervisor } \\
<10\end{array}$ & 1 & 1 & 10 & 12 \\
$10-19$ & 7 & 11 & 5 & 23 \\
$20-29$ & 1 & 4 & 0 & 5 \\
$30-39$ & 1 & 2 & 0 & 3 \\
$40-49$ & 0 & 1 & 0 & 1 \\
Sum & 10 & 19 & 15 & 44 \\
\hline
\end{tabular}

언어재활실습의 담당교수 1 인당 수강인원은 10 명 미만이 12 개 (27.3\%), 10-19명이 23개(56.8\%), 20-29명이 5개(52.3\%), 30-39명이 3 개(6.8\%), 40-49명이 1개(2.27\%)였고, 전문대와 대학교는 10-19명 이, 대학원은 10 명 미만이 가장 많았고(Table 11), 이러한 차이는 통 계적으로 유의하였다 $\left(\chi^{2}=17.321, p=.004\right)$.

언어재활현장실무는 10명 미만이 10 개(23.3\%), 10-19명이 14 개 (32.6\%), 20-29명이 4개(9.3\%), 30-39명이 7개(16.3\%), 40-49명이 3개 (7.0\%), 50명 이상은 4 개(9.3\%)였다. 학제 간에 유의한 차이를 보였 으며 $\left(\chi^{2}=18.828, p=.010\right)$, 전문대는 30-39명이, 대학교는 10-19명 이, 대학원은 10 명 미만이 가장 많았다(Table 12).

실습과목을 담당하는 교수진은 언어치료학 전공 여부 이외에 현 장에서 언어치료 경험 여부가 학생들의 임상지도에 매우 중요하므 로, 실습과목 담당교수의 전임/비전임 교원 여부, 언어재활사 자격 증 취득여부 및 언어재활사 임상경력을 조사하였고, 언어치료 임상 지도의 질적 수준을 조사하기 위하여 언어재활사 1 급과 2 급의 자 격증종류를 조사하였다.

언어재활관찰은 전임교원이 담당하는 경우가 30 개(69.8\%; 전문 대 8 개, 대학교 14 개, 대학원 8 개), 비전임교원(임상교원)인 경우 12 개(27.9\%; 전문대 1 개, 대학교 5 개, 대학원 6 개), 전임과 비전임이 같 이 있는 경우 1 개(2.3\%; 전문대 1 개)였고, 학제 간에 유의한 차이가 없이 세 학제 모두 월등하게 전임교원이 담당하는 경우가 많았다.
Table 12. Number of students per clinical supervisor in clinical field studies

\begin{tabular}{lcccc}
\hline & $\begin{array}{c}\text { Associate } \\
\text { degree }\end{array}$ & $\begin{array}{c}\text { Bachelor's } \\
\text { degree }\end{array}$ & $\begin{array}{c}\text { Master's } \\
\text { degree }\end{array}$ & Total \\
\hline $\begin{array}{l}\text { Number of students per supervisor } \\
<10\end{array}$ & 1 & 2 & 7 & 10 \\
$10-19$ & 3 & 5 & 6 & 14 \\
$20-29$ & 1 & 3 & 0 & 4 \\
$30-39$ & 4 & 3 & 0 & 7 \\
$40-49$ & 1 & 2 & 0 & 3 \\
$\geq 50$ & 0 & 4 & 0 & 4 \\
Sum & 10 & 19 & 14 & 43 \\
\hline
\end{tabular}

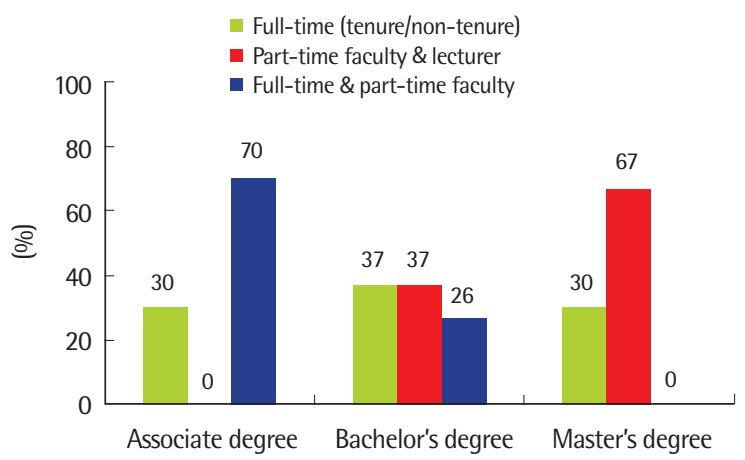

Figure 5. Faculty employment types in clinical practicum course.

언어진단실습은 전임교원이 담당하는 경우 22 개(53.5\%; 전문대 7 개, 대학교 11 개, 대학원 4 개), 비전임교원인 경우는 19 개(41.9\%; 전 문대 2 개, 대학교 7 개, 대학원 10 개). 전임과 비전임이 같이 담당하 는 경우가 2개(4.7\%; 전문대 1개, 대학교 1개)였고, 학제 간에 유의 한 차이는 없이 전임과 비전임이 담당하는 학교수가 유사하였다. 언어재활실습은 전임교원이 담당하는 경우가 15 개(34.1\%; 전문대 3 개, 대학교 7 개, 대학원 5 개), 비전임교원은 17 개( $38.6 \%$; 전문대 0 개, 대학교 7 개, 대학원 10 개), 전임교원과 비전임교원이 같이 하는 경우는 12 개( $27.3 \%$; 전문대 7 개, 대학교 5 개, 대학원 0 개)였으며, 학 제 간에 유의한 차이를 보였는데 $\left(\chi^{2}=17.201, p=.001\right)$, 전문대는 전 임교원과 비전임교원이 같이 지도하는 경우가 많았으나 대학교는 전임교원과 비전임교원의 담당이 같았으며, 대학원은 비전임교원 의 담당이 더 많았다(Figure 5). 언어재활현장실무는 전임교원이 담당하는 경우가 30 개 $69.8 \%$; 전문대 8 개, 대학교 13 개, 대학원 9 개), 비전임교원(임상교원)은 9개(48.8\%; 대학교 5개, 대학원 4개), 전임과 비전임이 같이 담당하는 경우는 4 개(9.3\%; 전문대 2 개, 대학 교 1 개, 대학원 1 개)였고, 학제 간의 유의한 차이 없이 전문대, 대학 교, 대학원 모두 비전임교원에 비해 전임교원이 담당하는 경우가 많았다. 
임상실습 교과목 교수진의 언어재활사 자격증을 조사한 결과, 43 개(100\%; 전문대 10개, 대학교 19개, 대학원 14개) 프로그램에서 언어진단실습 담당 교수진이 자격증을 소지하지 않은 1 개 대학교 를 제외하고 임상실습 교과목 담당 교수진 모두가 자격증을 소지 하였다.

담당 교수진의 자격증 형태는 Table 13과 같이 언어재활관찰의 경우 1 급 자격증이 41 개( $95.3 \%$; 전문대 10 개, 대학교 17 개, 대학원 14 개)였고, 2 급 자격증은 2 개( $4.7 \%$; 대학교 2개)였다. 언어진단실습 담당 교수진은 29개(67\%; 전문대 7 개, 대학교 10 개, 대학원 12 개)에 서 1 급 자격증 소지자였으며, 2 급 자격증을 소지한 경우는 14 개 (33\%; 전문대 3 개, 대학교 9 개, 대학원 2개)였다. 언어재활실습의 담 당 교수진은 1 급이 31 개( $70.5 \%$; 전문대 7 개, 대학교 12 개, 대학원 12 개), 2 급이 13 개( $29.5 \%$; 전문대 3 개, 대학교 7 개, 대학원 3 개)였고, 언 어재활현장실무의 담당 교수진도 1 급이 41 개(95.3\%; 전문대 9 개, 대학교 18 개, 대학원 14 개), 2 급이 2 개(4.7\%; 전문대 1개, 대학교 1개) 였으며, 임상실습 관련 4 개 교과목 모두에서 학제 간에 유의한 차이 없이 1 급자격증을 소유한 교수진이 담당하는 경우가 더 많았다.

담당 교수진의 임상경력을 살펴보면(Table 14), 언어재활관찰은 5년 미만이 19 개(44.2\%; 전문대 4 개, 대학교 7개, 대학원 8개), 5-10 년이 3 개(7.0\%; 대학교 2개, 대학원 1개), 10 년 이상은 총 16 개(37.2\%; 전문대 5 개, 대학교 8 개, 대학원 3 개), 무응답 5 개( $11.6 \%$; 전문대 1 개, 대학교 2개, 대학원 2개)였고, 언어진단실습은 자격증이 없는 교수 진이 있는 1개 프로그램을 제외하고, 5년 미만은 9개(21.4\%; 대학교 4 개, 대학원 5 개), $5-10$ 년은 19 개(45.2\%; 전문대 5 개, 대학교 11 개, 대
학원 3 개), 10 년 이상은 13 개(31.0\%; 전문대 3 개, 대학교 7 개, 대학원 3 개), 무응답 2 개(4.8\%; 전문대 1개, 대학원 1개)였으며, 언어재활실 습은 5년 미만이 0개(0\%), 5-10년은 25개(56.8\%; 전문대 6개, 대학 교 12개, 대학원 7개), 10 년 이상은 18 개(40.9\%; 전문대 4 개, 대학교 7개, 대학원 7개), 무응답이 1 개(2.3\%; 대학원 1개)였다. 그리고 언어 재활현장실무의 경우도 5년 미만이 5개(11.6\%; 대학교 3개, 대학원 2 개), 5-10년은 13 개( $30.2 \%$; 전문대 4 개, 대학교 5 개, 대학원 4 개), 10 년 이상은 25 개(58.1\%; 전문대 6개, 대학교 11 개, 대학원 8개)였다. 모든 임상실습 교과목의 담당 교수진 임상경력은 학제에 따라 유 의한 차이가 없었다. 다만, 대부분의 학제에서 언어재활관찰은 5 년 미만의 임상경력의 교수진이 많았고, 언어진단실습과 언어재활실 습은 5-10년의 경력이 있는 교수진이 많았으며, 언어재활현장실무 는 10 년 이상 경력의 교수진이 많았다.

담당교과의 평가를 담당하는 교원 정보를 살펴본 결과, 언어재 활관찰은 전임교원이 하는 경우가 30 개 $(70 \%$; 전문대 6개, 대학교 15 개, 대학원 9개), 비전임교원(임상교원)이 하는 경우는 7개(16.3\%; 대학교 2개, 대학원 5 개), 전임교원과 비전임교원(임상교원)이 함께 평가하는 경우는 6개(13.9\%; 전문대 4 개, 대학교 2개)였다. 이는 학 제 간에 통계적으로 유의한 차이를 보였으나 $\left(\chi^{2}=10.222, p=.018\right)$ 대부분의 학제에서 전임교원이 담당하는 경우가 많았다. 언어진단 실습은 전임교원이 담당하는 경우가 23개(53.5\%; 전문대 6개, 대학 교 12 개, 대학원 5 개), 비전임교원(임상교원)이 하는 경우가 8 개 (18.6\%; 전문대 3 개, 대학원 5 개), 전임교원과 비전임교원이 같이 평 가하는 경우가 12 개( $27.9 \%$; 전문대 1 개, 대학교 7 개, 대학원 4 개)였

Table 13. Clinical certification type (1st or 2nd grade) of faculties in clinical courses

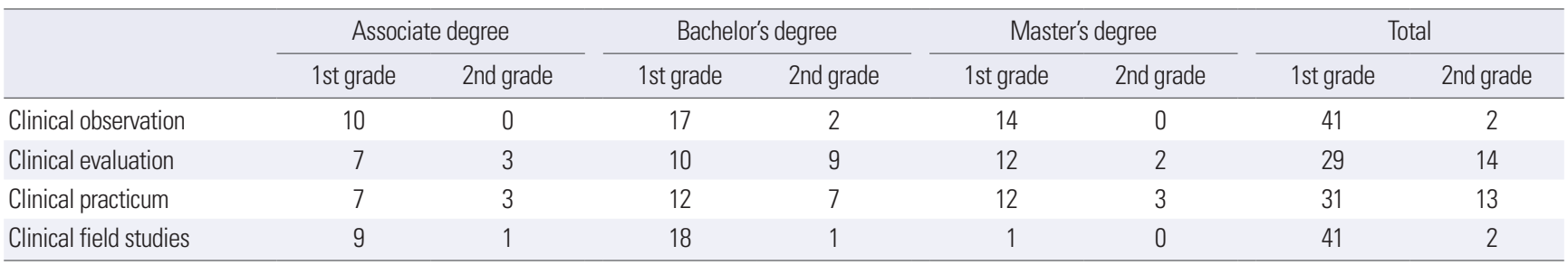

Table 14. Clinical career of faculties in clinical courses

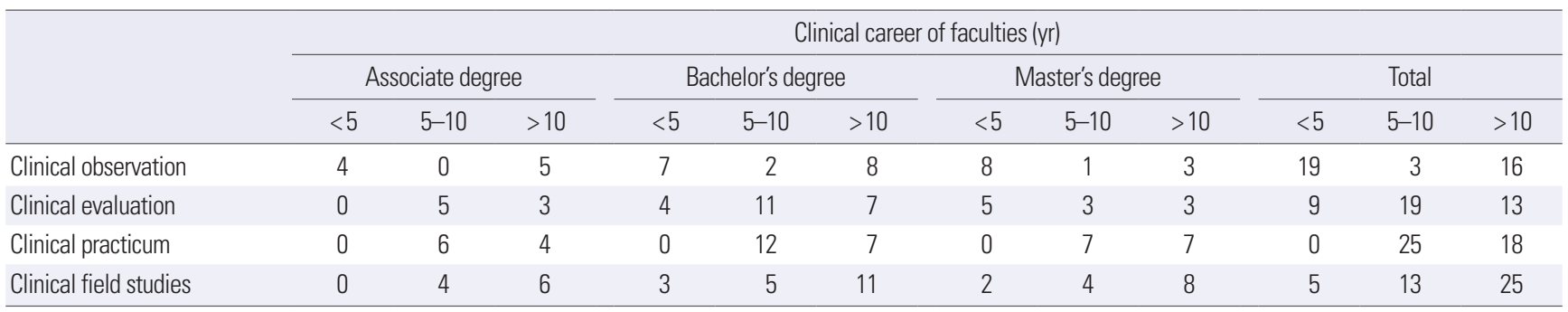


고, 학제 간에 유의한 차이를 보였으며 $\left(\chi^{2}=10.237, p=.028\right)$, 전문대 와 대학교는 전임교원이 언어진단실습의 평가를 담당하는 경우가 유의하게 많은 반면, 대학원은 전임교원과 비전임교원이 담당하는 경우가 동일하였다. 언어재활실습은 담당교과의 평가를 전임교원 이 하는 경우는 10 개(22.7\%; 전문대 2 개, 대학교 3 개, 대학원 5 개), 비전임교원이 하는 경우는 6 개(13.6\%; 대학교 2개, 대학원 4개), 전 임교원과 비전임교원이 같이 평가하는 경우는 28개(63.6\%; 전문대 8 개, 대학교 14 개, 대학원 5 개)로 학제 간에 유의한 차이는 없었다. 언어재활현장실무는 전임교원이 평가하는 경우가 32 개(74.4\%; 전 문대 9 개, 대학교 16 개, 대학원 7 개), 비전임교원이 하는 경우는 4 개 (9.3\%; 대학원 4 개), 전임교원과 비전임교원이 같이 평가하는 경우 는 7 개( $16.3 \%$; 전문대 1 개, 대학교 3 개, 대학원 3 개)로 학제 간에 통 계적으로는 유의한 차이를 보였으나 $\left(\chi^{2}=8.164, p=.045\right)$, 세 학제 모두 전임교원이 담당하는 경우가 많았다.

\section{임상실습 운영}

\section{교내 기본 임상실습}

전체 57 개 프로그램 중 대학원 1 개 프로그램을 제외한 56 개 프 로그램(98.2\%)이 '교내 임상실습지침서'가 있다고 응답하였다. 또 한 57개 모든 프로그램이 '사전교육(오리엔테이션)', '보고서 관련 피드백' 및 '강의평가/만족도 조사'를 실시하고 있으며, '임상실습 서식지/기록지'가 있다고 보고하였다. '임상감독 지침서'는 54개 (94.7\%; 전문대 10개, 대학교 18 개, 대학원 26개)에서 있다고 보고하 였고, 3 개(5.3\%; 대학교 1개, 대학원 2개)가 없었으며, 학제 간에 유 의한 차이 없었다. '학과 차원의 사례발표회'는 38 개(66.7\%; 전문대 7 개, 대학교 14 개, 대학원 17 개)가 실시한다고 하였고, 19개(33.3\%; 전문대 3 개, 대학교 5 개, 대학원 11 개)에서 실시하지 않는다고 하였 으며, 학제 간에 유의한 차이는 없었다.

임상실습감독 형태는 전체 57 개 프로그램(100\%)의 모든 프로그램 이 ‘임상실습교과목담당교수(감독자)가담당’한다고 응답하였다.

직접감독(감독자가 실습장면을 직접 관찰)과 간접감독(감독자 가 실습장면이 녹화된 동영상을 추후 시청하거나 보고서로만 피드 백)의 비율에 대한 질문에 응답한 47 개 프로그램 중 직접감독을
$100 \%$ 실시하는 프로그램이 6개(12.8\%)였고, 직접감독이 간접감독 보다 많은 프로그램이 7개(14.9\%)였으며, 직접과 간접의 비율이 $50: 50$ 으로 동일한 경우는 16 개(34.0\%)였다. 또한 간접감독이 직접 감독보다 많은 프로그램은 11 개(23.4\%)였고, 간접감독을 $100 \%$ 로 실시하는 프로그램은 7개(14.9\%)였고, 학제 간에 직접감독과 간접 감독 비율이 통계적으로 유의한 차이는 없었지만 전문대는 직접감 독에 비해 간접감독을 하는 경우가 가장 많았고, 대학교와 대학원 은 직접감독과 간접감독의 비율이 50:50인 경우가 가장 많았다 (Table 15).

임상실습 피드백/감독 주당 소요시간을 묻는 문항에는 총 48개 프로그램이 응답하였는데, 평균(표준편차)이 전문대(5개)는 5.00 시간(4.90), 대학교(17개)는 5.71시간(3.50), 대학원(26개)은 4.81시 간(2.73)이었고, 전체 범위가 주당 0-15시간으로 세 학제 간에 유의 한 차이는 없었으며, 세 학교 유형 모두 대체로 주당 4-6시간의 임 상 감독을 하고 있는 것으로 나타났다.

\section{실습장소, 실습영역 및 실습시간}

임상실습 장소로 절반 이상을 교내에서 실시해야 한다는 법적 규정에 근거하여 각 학교에서 임상실습이 교내에서 어느 정도로 이 루어지는지를 조사하였다(Table 16). 언어재활관찰을 실시하는 실 습장소로 응답한 43 개 프로그램 중 교내에서 이루어지는 경우는 11 개(25.6\%), 교외인 경우 3 개(7.0\%)였고, 교내와 교외에서 모두 실 시하는 경우가 29 개(67.4\%)였다. 언어진단실습의 실습장소로는 43 개 프로그램 중 교내에서 이루어지는 경우가 30 개(69.8\%), 교내와 교외에서 모두 실시하는 경우가 13 개(30.2\%)로서, 교외만인 경우 는 없었다. 언어재활 실습장소로는 44 개 프로그램 중 교내에서 이

Table 15. Ratio of direct (D) vs. indirect (I) supervision

\begin{tabular}{lcccccc}
\hline \multirow{2}{*}{ Type of school } & \multicolumn{5}{c}{ Ratio of direct vs indirect supervision } & \multirow{2}{*}{ Sum } \\
\cline { 2 - 6 } & $\mathrm{D}=100 \%$ & $\mathrm{D}>\mathrm{I}$ & $\mathrm{D}=\mathrm{I}$ & $\mathrm{D}<1$ & $\mathrm{I}=100 \%$ & \\
\hline Community college & 3 & 4 & 10 & 4 & 3 & 24 \\
Undergraduate & 0 & 2 & 1 & 5 & 0 & 8 \\
Graduate & 3 & 1 & 5 & 2 & 4 & 5 \\
Total & 6 & 7 & 16 & 11 & 7 & 47 \\
\hline
\end{tabular}

Table 16. Types of clinical practice sites (on-campus vs. off-campus)

\begin{tabular}{|c|c|c|c|c|c|c|c|c|c|c|c|c|}
\hline & \multicolumn{3}{|c|}{ Associate degree } & \multicolumn{3}{|c|}{ Bachelor's degree } & \multicolumn{3}{|c|}{ Master's degree } & \multicolumn{3}{|c|}{ Total } \\
\hline & On & Off & On+Off & On & Off & On+Off & On & Off & On+Off & On & Off & $\mathrm{On+Off}$ \\
\hline Clinical observation & 5 & 0 & 5 & 2 & 2 & 15 & 4 & 1 & 9 & 11 & 3 & 29 \\
\hline Clinical evaluation & 7 & 0 & 3 & 12 & 0 & 7 & 11 & 0 & 3 & 30 & 0 & 13 \\
\hline Clinical practicum & 5 & 0 & 5 & 7 & 0 & 12 & 5 & 0 & 10 & 17 & 0 & 27 \\
\hline Clinical field studies & 8 & 2 & 0 & 11 & 1 & 7 & 8 & 3 & 3 & 27 & 6 & 10 \\
\hline
\end{tabular}


루어지는 경우가 17 개(38.6\%), 교내와 교외에서 모두 실시하는 경 우가 27개(61.4\%)로서, 교외만인 경우는 없었다. 언어재활현장실무 는 43 개 프로그램 중 교내에서 이루어지는 경우는 27 개(62.8\%), 교 외인 경우는 6개(14.0\%), 교내와 교외에서 같이 이루어지는 경우는 10 개(23.3\%)였다. 임상실습 관련 4 개 교과목 모두 학제 간에 실습 이 이루어지는 장소는 유의한 차이가 없었으며, 언어재활관찰과 언 어재활실습은 세 학제 모두 교내와 교외에서 같이 이루어지는 경우 가 가장 많은 반면, 언어진단실습과 언어재활현장실무는 세 학제 모두주로 교내에서 이루어졌다.

한편, 실습의 주된 의사소통장애 영역으로 언어재활관찰은 학 령전기/학령기 언어발달장애가 가장 많았고, 언어발달장애 영역과 함께 관찰을 실시하는 다른 영역으로는 뇌성마비, 조음장애, 청각 장애가 많았다. 언어진단실습도 대부분 1 개 영역에서 실시하고 있 으며, 학령전기/학령기 언어발달장애가 가장 많았다. 언어재활실습 의 주된 의사소통장애 영역 또한 대부분 1 개 영역에서 실시하는 것 으로 학령전기 언어발달장애가 가장 많았다. 언어재활현장실무도 대부분 1 개 영역에서 언어재활현장실무를 실시하고 있으며, 학령 전기 언어발달장애가 가장 많았다.

언어재활현장실무에서 다루는 내용으로는 언어재활사의 역할 과 직무, 현장실무에서 다양한 현장(사설언어치료실, 병원언어치료 실, 장애인 복지관, 교육청, 다문화지원센터 등)에서 수행되는 바우 처와 같은 행정업무와 관련법규에 대한 제반 지식을 교육하고, 졸 업생이 근무하는 임상현장이나 현장의 임상가가 장애 영역별로 초 청되어 실제 임상과 치료에 대한 특강으로 진행되는 경우가 가장 많았으며, 임상현장에 대한 간접 경험을 쌓도록 진행하는 경우가 가장 많았다.

\section{임상실습시간의 적정성}

전체 57 개 프로그램 중 언어재활사 자격증 취득을 위해 법적으 로 규정하고 있는 임상실습시간의 적정성에 대해 응답한 56 개 프 로그램 중 '적절하다'라고 응답한 경우는 44 개(78.6\%; 전문대 8개, 대학교 12개, 대학원 24개), '부족하다'는 9개(16.1\%; 전문대 1개, 대 학교 5 개, 대학원 3 개), '많다'는 3 개(5.4\%; 전문대 1 개, 대학교 2개, 대학원 0 개)로 학제에 따라 응답의 유의한 차이가 없었으며, 세 학 제 모두 임상실습시간이 '적절하다’라는 응답이 가장 많았다.

\section{심화/현장실습}

심화/현장실습을 실시하는 프로그램은 전체 57개 프로그램 중 에서 45 개(78.9\%; 전문대 6개, 대학교 15개, 대학원 24개)였고, 실시 하지 않는 프로그램은 12 개( $21.4 \%$; 전문대 4 개, 대학교 4 개, 대학원
4개)로 학제 간 유의한 차이가 없이 심화/현장실습을 실시하는 프 로그램이 많았다.

심화/현장실습을 실시한다고 응답한 프로그램(45개) 중에서 심 화/현장실습을 실시하는 의사소통장애 영역에 대해 질문한 결과, '전 영역(언어장애, 조음장애, 유창성장애, 신경언어장애, 음성장 애)'을 모두 실습한다고 응답한 프로그램이 26개(57.8\%; 전문대 3 개, 대학교 8 개, 대학원 15 개)였고, 이 중 2개 프로그램에서 심화/현 장실습의 실습 영역은 2 학기 취업기관 또는 언어진단 및 재활실습 기관과 동일한 영역이라고 응답하였다. '언어/조음/유창성장애 영 역'을 주로 실습한다고 응답한 프로그램이 17 개(37.8\%; 전문대 2개, 대학교 7개, 대학원 8개)였으며, '신경언어/음성장애 영역'을 주로 실 습한다고 응답한 프로그램이 2 개(4.4\%; 전문대 1 개, 대학교 0 개, 대 학원 1 개)였다.

심화/현장실습을 실시하는 실습장소는 전체 45 개 프로그램 중 에서 8 개(17.8\%; 전문대 2개, 대학교 2개, 대학원 4개)가 교내에서 실시한다고 하였으며, 33 개(73.3\%; 전문대 4 개, 대학교 12개, 대학원 17 개)가 교외에서 실시한다고 하였고, 4 개( $8.9 \%$; 전문대 0 개, 대학 교 1개, 대학원 3개)가 교내와 교외 모두에서 실시한다고 하였으며, 세 학제 간에 심화/현장실습을 실시하는 장소는 유의한 차이가 없 었고, 세 학제 모두 교외에서 실시하는 경우가 가장 많았다.

\section{임상실습비 운용}

교내 임상실습비를 운용하는 프로그램은 전체 57 개 프로그램 중 51개(89.5\%; 전문대 5개, 대학교 19개, 대학원 27개)였고, 그렇지 않은 프로그램은 6 개( $10.5 \%$; 전문대 5 개, 대학교 0 개, 대학원 1개) 로 학제 간에 유의한 차이는 없었으며, 세 학제 모두 교내 임상실습 비를 운용하는 프로그램이 가장 많았다.

교내 임상실습비를 부담하는 주체에 대해 51개 프로그램이 응답 하였고, 그 중에서 25 개 프로그램(49.0\%; 전문대 3 개, 대학교 10 개, 대학원 12 개)이 학교라고 하였으며, 22 개 프로그램(43.1\%; 전문대 1 개, 대학교 8 개, 대학원 13 개)이 실습기관이라고 하였고, 학생개인 이라고 응답한 경우는 4 개 프로그램(7.8\%; 전문대 1 개, 대학교 1 개, 대학원 2개)이었다. 이는 학제 간에 유의한 차이는 없이 학교나 실 습기관에서 교내 임상실습비를 부담하는 경우가 많았다.

교외 임상실습비를 운용하는 프로그램에 대한 문항에서는 44개 프로그램이 응답하였고, 그 중에서 교외 임상실습비를 운용한다 고 응답한 경우는 24 개(54.5\%; 전문대 1 개, 대학교 8 개, 대학원 15 개), 교외 임상실습비를 운용하지 않는다고 응답한 경우는 20개 (45.5\%; 전문대 0 개, 대학교 8 개, 대학원 12 개)로 학제 간에 유의한 차이는 나타나지 않았다. 
교외 임상실습비를 운용한다고 응답한 프로그램(24개) 중에서 교외 임상실습비를 부담하는 주체에 대해 학교가 부담한다는 16 개 (66.7\%; 전문대 1개, 대학교 7개, 대학원 8개), 학생이 부담한다는 8 개(33.3\%; 전문대 0 개, 대학교 1 개, 대학원 7 개)로 학제 간에 유의한 차이 없이 학교가 부담하는 경우가 많았다.

\section{임상실습 면제}

전체 28개 대학원만을 대상으로 질문한 임상실습 면제가 있는지 를 묻는 문항에 대해 응답하지 않은 2 개를 제외한 26 개의 대학원 중에서 임상실습이 면제되는 경우는 17 개(65.4\%), 면제가 되지 않 는 경우는 9개(34.6\%)였다. 임상실습이 면제가 된다고 응답한 대학 원 중에서 4 개 대학원은 전체 임상실습의 $100 \%$ 를 완전히 면제하 는 것이 아니라 언어치료/재활 관련 대학교 전공자이거나 언어재활 사자격증 소지자의 경우 전체 임상실습의 $50 \%$ 를 감면해준다고 응 답하였다. 임상실습이 면제가 되는 사유로는 대부분이 언어치료/ 재활 관련 대학교 전공자 또는 언어재활사 자격증 소지자일 경우 임상실습을 선택할 수 있도록 하거나 전혀 실시하지 않는다고 하였 고, 2개 프로그램에서는 실습과목은 수강하되 실제 임상실습은 실 시하지 않고 사례발표 형식의 수업으로 이루어진다고 응답하였다.

임상실습을 면제하는 대학원 중에서 언어재활관찰, 언어진단실습 및 언어재활실습의 세 과목을 모두 면제하는 대학원이 14 개(82.4\%), 임상실습만 면제하는 대학원이 3 개(17.6\%)였다.

\section{$\mathrm{AAC}$ 임상실습}

$\mathrm{AAC}$ 임상실습과 관련된 문항들에 대해 응답한 프로그램은 전 체 57 개 중에서 38 개였다. AAC 실습 필요 여부를 질문하는 문항에 대해 필요하다고 응답한 경우는 29개(76.3\%; 전문대 1개, 대학교 11 개, 대학원 17 개)였고, 필요하지 않다고 응답한 경우는 9개(23.7\%; 전문대 1 개, 대학교 2개, 대학원 6 개)로 학제에 따른 차이는 없이 $\mathrm{AAC}$ 실습이 필요하다고 응답한 경우가 많았다.

$\mathrm{AAC}$ 실습 여건에 대해서는 38 개 프로그램 중에서 충족하다고 응답한 경우가 4 개( $10.5 \%$; 전문대 0 개, 대학교 2개, 대학원 2 개), 부 족하다고 응답한 경우가 32 개(84.2\%; 전문대 1 개, 대학교 10 개, 대 학원 21개), 그리고 준비 중이다라고 응답한 경우는 2개(5.3\%; 전문 대 1 개, 대학교 1 개, 대학원 0 개)였고, 학제 간에 유의한 차이 없이 세 학제 모두 $\mathrm{AAC}$ 실습 여건이 부족하다고 한 경우가 많았다.

$\mathrm{AAC}$ 실습을 실시하는지에 대해서는 38 개 프로그램 중에서 그 렇다고 응답한 경우가 22 개(57.9\%; 전문대 0 개, 대학교 10 개, 대학원 12 개)였고, 그렇지 않다고 응답한 경우는 16 개( $42.1 \%$; 전문대 2개, 대학교가 3 개, 대학원이 11 개)로 학제에 따라 유의한 차이가 없었다.
$\mathrm{AAC}$ 실습을 실시한다고 응답한 프로그램(22개) 중에서 $\mathrm{AAC}$ 실습 종류를 질문한 결과, low technology만을 사용하는 경우는 11 개(50.0\%; 대학교 3개, 대학원 8개)였고, low technology와 high technology 모두를 사용하는 경우는 11 개(50.0\%; 대학교 7개, 대학 원 4 개)로 학제에 따라 AAC 실습 종류의 차이가 없었다.

또한 보유하고 있는 $\mathrm{AAC}$ 실습 기자재의 종류에 관한 문항에 대 해 전체 56 개 프로그램 중에서 응답하지 않은 20 개 프로그램(전문 대 9 개, 대학교 5개, 대학원 6개)을 제외한 36개 프로그램(100\%; 전 문대 2개, 대학교 12개, 대학원 22개) 모두 low technology (그림카 드 등) 기자재를 보유하고 있으며, 그 외 high technology 기자재를 보유하는 프로그램은 총 15 개( $41.7 \%$; 전문대 0 개, 대학교 7 개, 대학 원 8개)였다. High technology 기자재 종류로는 다양한 어플, 마이 토키 보드, tablet PC, OK 톡톡 등이었고, 일부 학교에서는 프로그 램과 연계된 복지관이나 재활공학센터에서 $\mathrm{AAC}$ 기자재를 대여하 여 사용하고 있다고 응답하였다.

\section{임상실습 환경}

실습실

교내 실습실 유무에 관한 문항에 응답한 전체 57 개 프로그램 중 에서 ‘있다’고 응답한 경우는 56개(98.2\%)였고, 전문대 1개(1.8\%)만 없다고 응답하였으며, 이는 교내 실습실 대신 교외에서 모든 실습 이 이루어진다는 의미이다.

교내 실습실 전담 임상교수의 여부에 대한 질문에 전체 57 개 프 로그램 중에서 있는 경우는 51 개(89.5\%; 전문대 9 개, 대학교 18 개, 대학원 24 개)였고, 없는 경우는 6개(10.5\%; 전문대 1 개, 대학교 1개, 대학원 4개)였으며, 학제 간에 유의한 차이가 없이 세 학제 모두 대 부분 교내 실습실 전담 임상교수가 있음을 알 수 있다.

실습실의 담당조교의 유무는 전체 57 개 프로그램 중에서 47 개

Table 17. Types of assistants in clinical practice

\begin{tabular}{lcccc}
\hline Assistants in clinical practice & $\begin{array}{c}\text { Associate } \\
\text { degree }\end{array}$ & $\begin{array}{c}\text { Bachelor's } \\
\text { degree }\end{array}$ & $\begin{array}{c}\text { Master's } \\
\text { degree }\end{array}$ & Total \\
\hline No & 0 & 0 & 1 & 1 \\
Yes & 2 & 5 & 1 & 8 \\
Professor for clinical practicum & 2 & 0 & 0 & 2 \\
Off-campus SLPs & 0 & 7 & 14 & 21 \\
Doctoral students & 0 & 4 & 0 & 2 \\
Graduates with master's degree & 2 & 0 & 7 & 11 \\
Master's students & 0 & 1 & 1 & 2 \\
Undergraduate students & 6 & 17 & 24 & 47 \\
Sum & & & & \\
\hline
\end{tabular}

$S L P=$ speech-language pathologist. 
프로그램이 응답하였고, 이 중에서 없는 경우가 대학원 1개(2.1\%) 였으며, 있는 경우는 46 개(97.8\%)였다.

실습실의 담당조교가 있다고 응답한 경우에 담당조교의 유형은 Table 17과 같이 임상실습 담당교수인 경우는 8개(17.0\%), 외부기관 소속 언어재활사인 경우는 2 개(4.3\%), 박사과정인 경우는 21 개 (44.7\%), 석사졸업생인 경우가 2개(4.3\%), 석사과정생인 경우는 11 개(23.4\%), 4년제 대학교생/근로장학생인 경우는 2개(4.3\%)였다. 이 를 요약해보면, 전문대는 임상실습 담당교수, 외부기관 소속 언어 재활사 및 석사졸업생이 각 2개였고, 대학교(7개)와 대학원(14개) 은 박사과정생이 가장 많았으며, 그 다음으로 대학교는 임상실습 담당교수(5개)와 석사과정생(4개)이 많았으며, 대학원은 석사과정 생(7개)이 많았다.

실습실이 학교기업으로 운영되는지에 대한 질문에 전체 57 개 프 로그램 중 '그렇다'고 응답한 경우는 31개(54.4\%; 전문대 6개, 대학 교 12개, 대학원 13개)였고, '그렇지 않다'는 26개(45.6\%; 전문대 4 개, 대학교 7 개, 대학원 15 개)였고, 학제에 따라 유의한 차이가 없이 학교기업과 그렇지 않은 경우의 비율이 유사하였다.

실습실의 면적 $\left(\mathrm{m}^{2} /\right.$ 평 $)$ 에 응답한 프로그램은 42 개로, Table 18 과 같이 평균 \pm 표준편차가 전문대(6개)의 경우 $216.17 \pm 87.19 \mathrm{~m}^{2}$, 대 학교(11개)는 $169.82 \pm 80.27 \mathrm{~m}^{2}$, 대학원(25개)은 $167.08 \pm 103.01 \mathrm{~m}^{2}$ 로 세 학제 간에 유의한 차이가 없었다.

임상실습실의 개수에 대해 응답한 프로그램은 53개로, 평균士 표준편차가 전문대(9개)의 경우 $6.67 \pm 2.92$ 개, 대학교(16개)는 6.94 \pm 2.93 개, 대학원(28개)은 $6.29 \pm 3.30$ 개로 세 학제 간에 유의한 차 이는 없었다. Table 19에서 제시한 바와 같이 임상실습실은 전문대 가 대체로 5-8개, 대학교와 대학원은 6-8개였고, 임상실습실이 10

Table 18. Area of clinical practice $\left(\mathrm{m}^{2} / \mathrm{py}\right)$ by academic programs

\begin{tabular}{lcc}
\hline & Area $\left(\mathrm{m}^{2}\right)$ & Area $($ py) \\
\hline Associate degree $(\mathrm{N}=6)$ & $216.17 \pm 87.19(74-318)$ & $65.33 \pm 26.40(22-96)$ \\
Bachelor's degree $(\mathrm{N}=11)$ & $169.82 \pm 80.27(34-298)$ & $51.27 \pm 24.22(10-90$ \\
Master's degree $(\mathrm{N}=25)$ & $167.08 \pm 103.01(30-375)$ & $47.20 \pm 29.75(9-113)$ \\
Total $(\mathrm{N}=42)$ & $173.81 \pm 94.89$ & $50.86 \pm 28.02$ \\
\hline
\end{tabular}

개 이상인 경우도 전문대가 2 개, 대학교가 3 개, 대학원이 5 개였다. 임상실습실의 형태는 전체 57 개 프로그램(전문대 10 개, 대학교 19 개, 대학원 28개)이 모두 응답하였고, 이 중 개별 실습실만 있는 경우가 6 개( $10.5 \%$; 전문대 1 개, 대학교 2개, 대학원 3 개)였으며, 개별 과 그룹 실습실 모두가 있는 경우가 51개(89.5\%; 전문대 9개, 대학교 17 개, 대학원 25 개)였고, 학제 간 유의한 차이 없이 모든 학제가 개 별과 그룹 실습실이 더 많았다.

임상실습실에 일방향 거울(one-way mirror)이 있는지에 대해 전 체 57 개 프로그램이 모두 응답하였고, 이 중에서 '있다'고 응답한 경 우는 48개(84.2\%; 전문대 9개, 대학교 17 개, 대학원 22개), '없다'고 응답한 경우는 9 개( $15.8 \%$; 전문대 1개, 대학교 2개, 대학원 6개)였으 며, 세 학제에 따른 유의한 차이가 없이 대부분이 임상실습실에 일 방향 거울이 있었다. 일방향 거울이 없다고 응답한 대학원 중 1 개 프로그램은 일방향 거울 대신 CCTV가 설치되어 있다고 하였다.

임상실습실에 관찰실이 있는지에 대해 전체 57 개 프로그램이 모 두 응답하였고, 이 중에서 '있다’고 응답한 경우가 50개(87.7\%; 전문 대 10 개, 대학교 16 개, 대학원 24 개), '없다'고 응답한 경우는 7 개 (12.5\%; 전문대 0 개, 대학교 3 개, 대학원 4 개)였고, 세 학제 간에 유 의한 차이가 없이 모든 학제에서 관찰실이 있는 경우가 많았다.

임상실습실의 관찰실 내 음향시설이 설치되어 있는지에 대해 전 체 57개 프로그램이 응답하였고, '있다’고 응답한 경우는 55개(96.5\%; 전문대 9 개, 대학교 19 개, 대학원 27개), '없다'고 응답한 경우는 2개

Table 20. Number of additional clinical rooms

\begin{tabular}{lcccc}
\hline & $\begin{array}{c}\text { Associate } \\
\text { degree }\end{array}$ & $\begin{array}{c}\text { Bachelor's } \\
\text { degree }\end{array}$ & $\begin{array}{c}\text { Master's } \\
\text { degree }\end{array}$ & Total \\
\hline Voice lab & 5 & 8 & 8 & $21(32.3)$ \\
Hearing lab & 1 & 8 & 10 & $20(30.8)$ \\
Consulting room & 2 & 3 & 3 & $8(12.3)$ \\
Extra therapy room & 3 & 3 & 3 & $9(13.8)$ \\
Clinical meeting & 0 & 1 & 3 & $4(6.2)$ \\
Testing room & 0 & 1 & 2 & $3(4.6)$ \\
Sum & 11 & 25 & 29 & $65(100)$ \\
\hline
\end{tabular}

Values are presented as number (\%).

Table 19. Number of clinical practice rooms by academic programs

\begin{tabular}{|c|c|c|c|c|c|c|c|c|c|c|c|}
\hline & \multicolumn{10}{|c|}{ Number of clinical practice rooms } & \multirow{2}{*}{ Range } \\
\hline & 1 & 2 & 3 & 4 & 5 & 6 & 7 & 8 & 9 & $>10$ & \\
\hline Associate degree $(\mathrm{N}=6)$ & 1 & 0 & 0 & 0 & 2 & 2 & 0 & 1 & 1 & 2 & $1-10$ \\
\hline Bachelor's degree $(\mathrm{N}=15)$ & 0 & 1 & 1 & 1 & 1 & 4 & 2 & 3 & 0 & 3 & $2-13$ \\
\hline Master's degree ( $\mathrm{N}=26)$ & 1 & 3 & 3 & 3 & 2 & 4 & 0 & 6 & 1 & 5 & $1-13$ \\
\hline Total (N=52) & 2 & 4 & 4 & 4 & 5 & 10 & 2 & 10 & 2 & 10 & $1-13$ \\
\hline
\end{tabular}


Table 21. Test tools and equipment for evaluating communication disorders

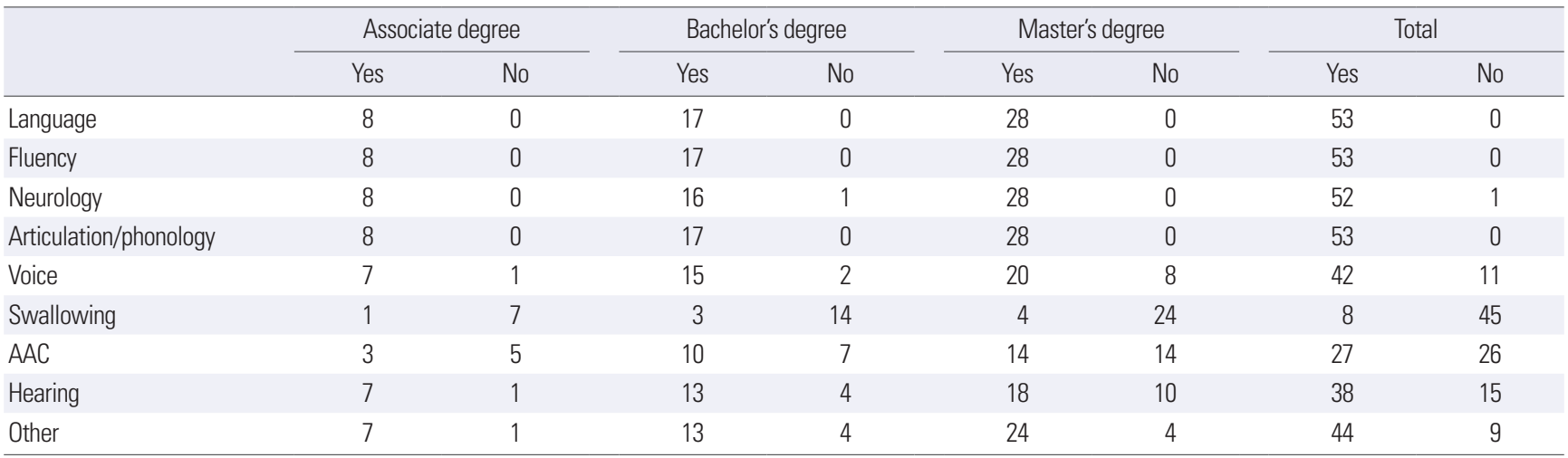

$\mathrm{AAC}=$ augmentative and alternative communication.

(3.6\%; 전문대 1 개, 대학교 0 개, 대학원 1 개)였고, 학제 간에 유의한 차이가 없이. 대부분이 관찰실 내 음향시설이 설치되어 있었다.

임상실습실에 준비실이 있는지에 대해서도 전체 57 개 프로그램 이 모두 응답하였고, '있다'고 응답한 경우가 55 개(96.5\%; 전문대 10 개, 대학교 19개, 대학원 26개), ‘없다’고 응답한 경우는 대학원만 2 개(3.6\%)였고, 학제 간 유의한 차이가 없이 대부분 준비실이 있었다.

언어치료실 외에 다른 치료실이나 검사실이 있는지에 대해 54 개 프로그램(전문대 9개, 대학교 17개, 대학원 28개) 중에서 '있다'고 응답한 프로그램은 모두 41 개(75.9\%; 전문대 8 개, 대학교 14 개, 대 학원 19개)였고, '없다’고 응답한 경우는 모두 13 개(24.1\%; 전문대 1 개, 대학교 3개, 대학원 9개)였으며, 학제에 따라 유의한 차이가 없 이 대부분이 다른 치료실이나 검사실이 있다고 하였다. 이 중에서 다른 치료실이나 검사실이 있는 경우 음성검사실은 21 개, 청각실은 20 개, 상담실은 8 개, 다른 분야 치료실은 9 개, 임상미팅실은 4 개, 그 리고 검사실은 3 개 프로그램에서 있었으며, 전문대에는 음성검사 실(5개)과 다른 치료 분야의 치료실(4개)이 많았고, 대학교와 대학 원은 청각검사실(10개)이 가장 많았고, 그 다음으로 음성검사실(8 개)이 많았다(Table 20).

\section{검사도구 및 기자재}

의사소통장애 영역별 검사도구 및 기자재 유/무에 관한 문항들 에 대해 4 개 프로그램(전문대 2개, 대학교 2개)을 제외한 53개 프로 그램이 응답하였다. 의사소통장애 검사도구 및 기자재를 영역별로 구분해 보면(Table 21), 언어장애, 유창성장애, 조음음운장애는 모 든 53 개(100\%)가 '있다'고 하였고, 신경언어장애는 대학교 1 개를 제 외한 52개 프로그램(98.1\%)이 '있다’고 하였다. 음성장애는 '있다’고 응답한 경우가 42개(79.3\%)와 ‘없다’고 응답한 경우가 11 개(20.7\%) 였으며, 삼킴장애는 ‘있다’고 응답한 경우가 8개(15.1\%), '없다'고 응
답한 경우가 45 개(84.9\%)였다. $\mathrm{AAC}$ 는 '있다'고 한 경우가 27개 (50.9\%), '없다'고 한 경우가 26개(49.1\%)였고, 청각장애는 '있다'고 응답한 프로그램이 38 개(71.7\%), '없다’고 응답한 프로그램이 15개 (28.3\%)였으며, 그 외 검사도구나 기자재가 ‘있다’고 응답한 경우가 44개(83.0\%), ‘없다’고 응답한 경우가 9개(17.0\%)였다.

\section{기타}

임상실습과 관련하여 그 외 주관식으로 질문한 임상실습 운영 시에 어려운 점에 대해 응답한 프로그램은 21 개(전문대 1 개, 대학 교 6개, 대학원 14개)였다. '임상실습 대상자 부족 및 제한적 대상자 (아동으로 국한)'라는 응답이 7 개(대학교 3개, 대학원 4개)로 가장 많았고, 임상실습은 한 명의 감독자가 소규모로 감독을 해야 하므 로 '분반이나 시수로 인한 학교 예산 부족'이 6개(전문대 1개, 대학 교 1개, 대학원 4 개)였다. 그 다음으로 '다양한 의사소통장애 영역 의 실습이 어려움, '실습 공간 부족' 및 '실습생들의 태도 문제'가 각 3 개 (대학교 1 개, 대학원 2개) 프로그램에서 응답하였고, 특수대학 원의 경우 ‘임상실습시간 마련의 어려움’이 2 개 프로그램에서 응답 하였다. 또한 기타 의견으로 '외부 임상실습을 실시할 경우 이에 대 한 실습비와 실습지도 매뉴얼 등과 같은 외부실습 운영 사항에 대 한 전국적 조사와 관리가 필요하다'는 의견이 있었다.

임상실습 운영 개선을 위한 제언에 대해 4 개(전문대 1 개, 대학교 1 개, 대학원 2개) 프로그램이 응답을 하였는데, '체계적인 실습 감 독자 교육과 ‘감독자의 증원을 위한 학교의 재정적 지원'이 주된 답 변이었다.

\section{논의 및 결론}

본 연구는 국내 언어치료 교육기관인 3년제 전문대학, 4년제 대 
학교, 대학원의 학과장이나 임상실습 관련 담당교원을 대상으로 임상실습과 관련된 교육과정, 임상실습 운영 현황 및 임상실습 환 경에 대한 전반적인 정보를 수집하고 국내 임상교육현장의 현황을 파악하는데 목적을 두었다. 2010년에도 국내 언어치료학과 총 41 개 의 교육기관(전문대 8, 대학교 14, 대학원 19) 중에서 응답한 총 23 개의 교육기관(전문대 7, 대학교 7, 대학원 9)을 대상으로 학과인증 제를 위해 교육환경 및 여건을 분석한 연구가 시행되었으나(Kwon et al., 2010), 임상 교과와 교과 운영에 대한 조사는 이루어지지 않 았다. 또한, 2012년 언어재활사 국가자격증 전환 이후 급속도로 언 어치료학과가 양적으로 증가하였으며, 현재 총 87개의 프로그램(사 이버대와 산업대를 포함하면 총 90 개 프로그램)이 운영 중에 있어 국내 언어치료학과 프로그램의 임상실습 교과와 실습에 대한 질적 제고를 고려해 볼 시점이다.

본 연구에 참여한 국내 57 개의 언어치료 프로그램의 응답 결과, 실습 교과목 개설에 있어서는 교육기관마다 언어재활사 국가 자격 증을 취득하기 위한 최소한의 요건인 언어재활관찰, 언어진단실습, 언어재활실습 및 언어재활현장실무 과목이 개설되어 있었으나 학 점, 시수 및 과목별 교육 형태의 실습교과목 운영 방식이 교육기관 마다차이가 있었다. 언어재활관찰은 1-6학점 혹은 1-6시수였고, 언 어진단실습은 2-8학점과 2-14시수, 언어재활실습은 2-8학점과 2-11 시수, 언어재활현장실무는 1-3학점과 1-6시수로 학교마다 매우 다 양하였고, 일반적으로 전문대와 대학교는 3학점에 4-6시수로 운영 되는 곳이 많아 학점에 비해 시수가 많은 반면, 대학원은 2학점에 2 시수로 학점과 시수가 일치하는 경우가 많았다. 학교와 학제 간의 이러한 차이는 언어재활사 응시 자격으로 임상실습 관련 교과목의 학점이나 시수가 아닌 총 관찰시간과 임상실습시간이 규정되어 있 고, 대학원의 경우 학부와 달리 4-5학기 내에 응시 자격과 관련된 과목들을 모두 이수하기 위해서는 최소한의 학점과 시수로 운영되 어야 하기 때문에 나타난 결과로 보인다.

실습과목의 교과목 형태를 살펴보면, 언어재활관찰과 언어재활 현장실무는 모든 학제가 전공필수와 전공선택으로 개설된 학교 수 가 유사하였으나 언어진단실습과 언어재활실습은 전문대와 학부 는 전공선택이 좀 더 많은 반면, 대학원은 전공필수가 더 많았다. 이 러한 요인으로 학부 교과과정이 학생들에게 다양한 수강 선택권을 부여한다는 교육부의 방침에 따라 전공필수 교과목을 감소시키는 것에서 기인한다고 볼 수 있다. 또한 언어치료 외에 다른 전공(예: 청 각학, 상담학)을 함께 운영하는 프로그램에서는 언어치료의 전공 필수 교과목이 더 감소하게 될 수 밖에 없기 때문으로 보인다. 다만, 언어재활사 국가 시험에 응시하기 위해서는 임상관련 4 개 교과목 을 반드시 이수해야 하는 과목이기 때문에 전공필수 또는 전공선
택의 다른 형태로 개설되는 것이 큰 의미는 없다고 여겨진다.

임상실습 교과목의 수업 방식은 4 개 모든 교과목에서 이론으로 만 실시하는 경우는 한 학교도 없었고, 대부분 실습 위주로 진행하 고 있었다. 그러나 언어재활실습의 경우 전문대와 대학원은 실습을 위주로 하는 반면, 대학교는 이론과 실습을 병행하는 경우가 더 많 았는데, 재학생의 수가 상대적으로 많은 대학교의 경우 임상실습 대상자가 부족한 실습 여건으로 인해 실습의 기회가 충분히 주어 지지 않기 때문일 것으로 추측된다. 실제로 임상실습 운영 시 어려 운 점에 대한 주관식 질문에서 '부족한 임상실습 대상자와 제한된 장애 영역'이라고 응답한 경우가 많았다. 따라서 추후에 이에 대한 좀 더 심도있는 검토가 필요해 보인다.

임상실습 교과목 수강 전 선수 교과목의 이수는 모든 학제에서 언어재활관찰과 언어재활현장실무는 없다고 한 경우가 많은 반면, 언어진단실습과 언어재활실습은 대부분의 학제에서 선행과목을 이수하여야만 수업을 이수할 수 있었다.

임상실습 교과목의 담당교수 1 인당 수강인원을 살펴본 결과, 언 어재활관찰을 제외한 대부분의 교과목에서 수강인원이 전문대와 대학교는 10-19명, 대학원은 10명 미만인 경우가 많았고, 이는 각 학 제의 재학생 수와 비례하기 때문으로 볼 수 있다. 다만, 본 연구에서 는 살펴보지 못했지만 담당교수 1 인당 수강인원 외에 학생들이 직 접 관찰하는 사례수나 기관수 그리고 직접 실습을 담당하는 실습 대상자 수에 대한 정보를 추가적으로 살펴본다면 임상실습에서 실 제 실시하는 실습 현황을 보다 면밀히 알 수 있을 것으로 보인다.

실습 담당 교수진을 살펴보면, 임상관찰과 언어재활현장실무는 전체 프로그램의 약 $70 \%$, 언어진단실습은 약 $53 \%$ 를 전임교원이 담 당하는 반면, 언어재활실습은 비전임교원(임상교원)이 담당하는 경 우가 가장 많았으며, 약 $38 \%$ 를 차지하였다. 이렇게 언어진단실습과 언어재활실습의 전임교원의 담당 비율이 상대적으로 낮은 것은 학 교마다 실습실에 임상교원들을 배치하여 임상실습만을 전담하도 록 하기 때문으로 보인다. 임상실습 담당 교수진은 1 개 대학교의 언 어진단실습을 담당하는 교수진을 제외하고 모두 언어재활사 자격 증을 소지하였고, 모든 학제에서 1 급 자격증 소지자가 2 급 자격증 소지자에 비해 더 많았으며, 이들의 임상경력은 모든 학제에서 언어 재활관찰은 5년 미만이 가장 많았고, 언어진단실습과 언어재활실 습은 모두 5-10년, 언어재활현장실무는 10년 이상이 가장 많았다.

실습 교과목의 평가는 언어진단실습을 제외한 모든 임상실습 교 과목에서 세 학제 모두 전임교원이 실시하는 경우가 많았으나 언어 재활실습은 세 학제 모두 전임교원과 비전임교원(임상교원)이 평가 를 담당하는 경우가 가장 많아 임상에서 치료 실습을 직접 할 경우 임상을 전담하는 교원이 평가하는 경우가 많음을 알수 있다. 
보다 전문적인 언어재활사를 양성하기 위해서 임상실습 교육이 중요하다는 사실은 이미 알고 있다. 이와 함께 임상실습 교육을 운 영하는 방식 또한 중요할 것이다. 본 연구에 참여한 학과 프로그램 들을 대상으로 임상실습 운영 방식을 살펴본 결과, 모든 학제의 대 부분이 사전교육, 보고서 피드백, 강의평가, 임상실습 서식지와 지 침서, 사례발표회 등을 실시하고 있어 임상실습을 위해 기본적으 로 갖추어야 할 운영 방식을 취하고 있었다. 임상실습의 감독 형태 에 있어서는 감독자가 실습장면을 직접 관찰하는 직접감독에 비해 감독자가 실습장면이 녹화된 동영상을 추후 시청하거나 직접 실습 장면을 관찰하지 않고 보고서로만 피드백을 실시하는 간접감독의 형태 및 직접과 간접감독이 혼합된 형태가 더 많았다. 간접감독은 실습에 대한 실시간적인 피드백을 제공하기 어렵고 화면이나 보고 서에 제시된 제한된 정보에 대해서만 감독할 수 있기 때문에 충분 한 감독이 이루어진다고 보기 어렵다. 물론 제한된 수의 임상감독 자와 실습 환경으로 인해 모든 실습생의 실습장면을 직접 관찰하 여 1:1로 감독하는 것이 용이하지는 않겠지만 실습감독을 통해서 실습생이 훈련되기 때문에 보다 직접적인 감독의 형태로 운영하도 록 노력해야 할 것이다. 임상실습 피드백 및 감독에 소요되는 시간 은 학제 간의 차이 없이 주당 4-6시간이 가장 많았다.

양질의 임상실습을 위한 시간과 공간 확보는 전문가 양성에 필 수적이다. 실습 시간이 충분히 길고, 다양한 장애 영역을 실습하며, 교내에서 학과의 관리하에 임상실습이 운영되는 것이 필요하다. 본 연구결과, 실습장소는 임상실습시간의 절반 이상이 교내에서 이루 어져야 한다는 법적 규정과 관련하여 모든 교과목이 교외에서만 이루어지는 프로그램은 거의 없었지만 언어재활관찰의 경우에는 교과목의 특성상 교내에서 관찰할 수 없는 다양한 장애 영역을 관 찰하기 위해 병원이나 전문치료실을 중심으로 이루어지는 교외 관 찰실습이 많은 부분 이루어지고 있었다. 다만 각 프로그램마다 다 른 실습환경으로 인해 언어재활실습은 교외에서도 일부 많은 부분 을 시행하는 것으로 나타났다.

각 학교에서 실시되는 실습 영역은 매우 제한적으로 이루어지고 있었는데, 거의 대부분의 프로그램에서 한 가지 영역에서 실습이 주로 이루어졌으며, 대부분 언어발달장애 분야에 국한되어 있었다. 국내의 경우 언어발달장애 영역의 수요가 가장 많기는 하지만 졸업 후 임상현장에서 언어발달장애 영역 이외에 말소리장애, 음성장 애, 유창성장애, 신경언어/말장애, 청각장애 등 다양한 영역의 장애 군들을 접하게 될 뿐 아니라 병원이나 전문 치료기관에서는 특정 영역에 대한 치료지식을 필요로 한다. 이에 언어재활사 양성 프로 그램에서는 보다 다양한 장애 영역을 실습할 수 있는 기회를 제공 해야 할 것이며, 이러한 실습 환경을 조성하는 것이 어렵다면 보다
상위의 학제나 보수교육을 통한 특정 장애 영역의 전문가 양성을 위한 전문적 실습교육이 필요하다. 또한, 비록 일부 대학원에서는 2 급 자격증 소지자 학생들에게는 임상실습을 면제해주고 있으나, 전문적인 영역에서의 실습이 추가적으로 실시되고 강화되어야만 양질의 학생들이 배출될 것으로 생각된다.

현행 규정하고 있는 임상실습시간이 졸업 후 바로 언어치료서비 스를 제공하는 전문가 양성을 위해 충분하다고 여겨지지는 않지만 임상실습시간만을 증가시킨다고 제대로 실습을 지도할 수 있는 여 건이 되는 프로그램은 많지 않을 것이다. 최근 융합교육의 중요성 이 강조되고 있는 가운데, 한 프로그램에서 두 개의 자격증이나 복 수 전공을 운영하는 프로그램이 점차적으로 증가하고 있어 임상실 습 학점이나 시수가 감소하고 있기 때문에 임상실습시간이 최소한 으로 이루어지고 있는 경우가 많다. 이에 자격증 취득을 위한 현행 법정 규정 임상실습시간이 적절한지를 조사한 결과, 약 $80 \%$ 의 프 로그램에서 자격증을 위한 임상실습시간이 적절하다고 응답하였 으나 교육적인 측면을 고려한다면 여전히 부족하다고 응답하기도 하였다. 부족하다고 응답한 경우는 추가적으로 심화실습이나 현장 실습 교과목을 통해 운영하고 있었다. 그리고 많은 경우 교과목에 배정되는 학점이나 시수가 점차 줄어드는 상황으로 인해 임상실습 지도와 감독자 섭외가 어려워 임상실습시간을 확대하는 것은 환경 여건상 어려움이 있다고 토로하였다.

심화/현장실습을 실시하는 곳은 설문에 응답한 프로그램의 약 $80 \%$ 였고, 모든 학제에서 대부분 교외에서 심화/현장실습이 이루어 지며, 이 중 절반 정도가 5 대 장애 영역(언어, 조음, 유창성, 음성, 신 경언어)를 실시하고 있다고 응답하여 기본적인 임상실습은 교내에 서 언어발달장애 중심으로 이루어지지만 그 외 장애 영역은 심화/ 현장실습을 통해 교외에서 실시하려고 노력하고 있음을 알수 있다. 임상실습비 운용은 약 $90 \%$ 가 교내 임상실습비를 운용하고 있었 으며, 교내 실습비는 주로 학교로부터의 지원이나 치료를 받는 대 상자들이 실습기관에 지불하는 실습비를 통해 지급되고 있었다. 그러나 일부 교외 실습을 실시하는 경우 모든 학제에서 학생 비용 부담이 증가하는 경향을 보였다.

대학교나 대학원의 임상실습의 경우 임상실습 교과목을 개설하 지 않거나 임상실습시간을 면제하는 경우가 있다고 응답한 경우는 전체 프로그램의 $65 \%$ 에 달했는데, 이는 전문대나 대학교를 통해 이미 자격증을 취득하고 상위 학위 과정에 진학한 전공자들에게 임상실습 교과목이나 실습시간을 면제해 주거나 학부와 대학원 과 정을 함께 운영하는 학교의 경우 학부 과정을 통해 비교적 유연하 게 임상실습 관련 교과목을 운영하고 있기 때문이다. 임상실습을 면제하지 않는 경우는 약 $15.4 \%$ 로 전체 임상실습시간의 $50 \%$ 를 이 
수하게 한다거나 임상실습 관련 교과목을 수강하되 실습시간은 이 수하지 않고 사례 발표형식으로 수업이 이루어지고 있었다.

서론에서 언급한 바와 같이 최근 필요성과 국가적 지원의 확대 로 인해 $\mathrm{AAC}$ 에 대한 필요성이 증가하고 있어 본 연구에서도 기본 적인 임상실습 외에 $\mathrm{AAC}$ 실습과 관련하여 질문하였다. 응답한 대 부분(76\%)의 프로그램에서 $\mathrm{AAC}$ 임상실습이 필요하다고 응답하 였지만 AAC 실습 여건은 대부분(84\%) 부족하다고 응답하여 AAC 실습 환경을 조성하기 위한 재원 확보가 필요한 것으로 나타났다. 또한, $\mathrm{AAC}$ 실습을 시행하는 곳은 약 $58 \%$ 로 절반이 조금 넘었으나 대부분 비전자적 도구(low-technique)만 사용하고 있었고, 하이테 크도구(high-technique)를 같이 사용하는 경우는 많지 않았다. 특 히, 사용하고 있는 하이테크도구 기자재로는 다양한 어플이나 마 이토키 보드, tablet PC, OK 톡톡 등이 있었다. 미국의 경우, $\mathrm{AAC}$ 가 다학문적 영역이지만 많은 언어재활사가 $\mathrm{AAC}$ 사용자들에 대 한 평가와 중재에 관여하기 때문에 $\mathrm{AAC}$ 영역에 관한 훈련은 언어 재활사에게 매우 중요하게 다루어지고 있다(Beukelman \& Miren$\mathrm{da}, 2005)$. 미국의 한 조사에 의하면, 언어재활사 프로그램의 약 $62 \%$ 가 최소 한 개의 AAC 과정을 가르치고 훈련하였다(Koul \& Lloyd, 1994). AAC는 구어적 산출이 어려운 중증의 의사소통장애 가 있는 대상자들에게 매우 효율적으로 사용될 수 있음에도 불구 하고 AAC 기자재를 구비하기 위해서는 많은 재원이 요구되기 때 문에 쉽게 접근하기 어려운 분야이기도 하다. 그러나 과학기술의 발전으로 4 차산업혁명 시대를 눈앞에 두고 있는 시점에서 국내 언 어치료 분야도 좀 더 그 영역을 확장시켜 나아가고 SLP의 업무도 진 화해야 한다. 디지털 및 말기록이나 분석 기술은 이미 사용되고 있 으며, 의사소통의 어려움을 가진 사람들을 위해 보조공학 기술이 나 다양한 보장구를 이용할 수 있다. 국내에서도 보장구 사용에 대 한 가능한 모든 자료와 정보를 동원하여 최상의 전문적 서비스를 제공해야 한다고 SLP의 역할이 명시되어 있지만, 실제 교육현장에 서는 거의 이루어지지 않고 있었다. 따라서 더 다양한 대상자들에 게 양질의 실질적인 치료접근을 제공하기 위해서는 양성기관인 학 교기관에서 우선적으로 이와 관련된 실습교육을 시켜야 할 것이 며, 이에 대한 필요성을 좀 더 강조할 필요가 있다.

마지막으로 임상실습 환경에 대한 현황을 분석한 결과, 전문대 1 개를 제외하고 모두 교내 실습실이 갖추어져 있었고, 응답 프로그 램의 $90 \%$ 가 교내에 실습실 전담 임상교수가 있었다. 실습실 담당 조교는 대학원 1 개 프로그램을 제외하고 모두 있었으며, 학부와 대 학원은 박사과정생이 가장 많은 반면, 전문대는 석사졸업생 혹은 외부기관 소속 언어재활사가 가장 많았다. 실습실이 학교 기업으로 운영되는 프로그램은 전체 중 절반 이상(55\%)이었으며, 실습실 면
적은 30-375 $\mathrm{m}^{2}$ (평)으로 매우 다양하였으나 평균적으로 170-220 $\mathrm{m}^{2}$ (평)으로 학제 간에 차이는 없었다. 실습실 개수는 평균 6-7개로 학제 간에 유의한 차이는 없었고, 임상실습실의 형태는 거의 대부 분의 프로그램이 개별실습실과 그룹치료실을 모두 갖추고 있었다 (90\%). 또한, 응답 학교 대부분이 임상관찰실(88\%), 임상실습 준비 실(97\%)이 갖춰져 있었고, 시설로는 실습실 내 관찰실에 일방향 거 울(84\%), 관찰실 내 음향시설(97\%)이 대부분 갖춰져 있었으며, 언 어치료실 외에 다른 치료실이나 검사실이 있는 경우도 약 $76 \%$ 에 달 하였고, 음성검사실과 청각검사실이 대부분으로 대부분의 프로그 램이 교내 임상실습을 잘 운영하고 있음을 알수 있다.

임상실습실의 검사도구와 기자재는 언어장애, 유창성장애, 조음 음운장애 검사도구나 기자재는 모든 학교 프로그램이 구비하고 있 었으나 음성장애, 삼킴장애, $\mathrm{AAC}$, 청각장애, 삼킴장애 기자재는 상대적으로 적은 편이었다.

기타 의견으로 실습과 관련하여 운영하는 데 어려운 점으로 대 부분의 프로그램들이 임상실습 대상자의 부족과 아동에 국한되는 제한적 대상자로 인한 제한된 장애 영역만의 실습 등을 가장 큰 어 려움으로 호소하였고, 분반이나 시수로 인한 학교 예산 부족으로 임상감독자의 섭외가 어려울 뿐 아니라 한 감독자가 많은 학생을 감독해야 하는 어려움이 있다고 지적하였다.

전문적인 언어재활사를 양성하기 위해서는 학교 임상실습과 임 상현장 간 격차를 줄이는 것이 매우 중요하다. 양질의 임상실습을 통해 전문적인 언어재활사를 배출하기 위해서는 임상실습 교과과 정의 운영 체계의 지침이나 관리 감독이 필요하다. 그러나 아직까지 국내 전반의 언어치료학과 임상실습 교육과정의 운영 실태에 대한 보고가 이루어지지 않았으며, 국내에서는 임상실습에 대한 모든 관리감독을 학교 자체 내에서 관장하여 운영하므로 실제 임상실습 교과과정이 잘 운영되고 있는지에 대한 관리감독은 명확하지 않은 실정이다. 특히 국가 자격증과 관련되어 신설된 언어재활현장실무 교과목의 경우에는 시행된 지 5년 정도밖에 되지 않고 기초적인 가 이드라인마저 없기 때문에 프로그램마다 매우 상이하게 운영되고 있다. 이는 본 연구에서 산출된 결과를 통해서도 알 수 있다. 또한 본 연구의 설문조사에 응답하지 않은 학교들은 어떠한 방식으로 실습이 운영되고 있는지 파악하기 어렵기 때문에 본 조사의 한계가 있다고 볼 수 있다. 이에 추후에는 언어치료 프로그램을 운영하는 모든 학제들의 임상실습을 포함한 교육과정 전반을 좀 더 면밀히 살펴보고 임상실습 교과과정 운영 체계의 지침을 보다 일원화함과 동시에 언어치료 프로그램 인증제와 같은 적극적인 관리체제를 도 입함으로써 국내 언어치료 프로그램들에서 운영하는 임상실습의 질적 수준을 향상시킬 필요가 있다. 
미국의 경우 $\mathrm{ASHA}$ 에서 SLP의 전문성과 경험, 의뢰인의 가치, 연 구 증거를 근거로 한 가능한 최선의 정보를 제공하여 최선의 임상 중재에 대한 책임을 잘 수행하기 위하여 의사소통장애 근거기반임 상실무 국립센터(The National Center for Evidence-Based Practice in Communication Disorders)를 설립하여 포괄적 평가와 중재를 위한 임상 가이드라인을 수립하고 있다(American Speech, Language, \& Hearing Association, 2014; Owens, Farinella, \& Metz, 2015). 따라서 국내에서도 여러 학제와 프로그램별로 다양하게 이 루어지고 있는 임상실습 교육환경과 내용에 대한 공통적인 지침과 가이드라인을 마련하는 것이 절실히 요구되며, 본 연구에서 제시된 결과들은 이러한 지침을 마련하는 기초적인 자료가 될 수 있을 것 으로 본다. 또한 SLP들이 사설치료실, 병원, 클리닉, 공립학교 이외 에도 대학, 정부기관, 산업체, 연구소 등 다양한 분야에서 활동할 수는 있지만 국내 여건에서는 사설치료실에서 근무하는 경우가 대 부분으로 제한된 장애 영역만을 다룰 수밖에 없을 뿐 아니라 언어 치료서비스를 제공받는 대상자의 입장에서도 제한된 제공지로부 터 제한된 서비스를 제공받을 수 밖에 없기 때문에 점차적으로 $\mathrm{SLP}$ 의 근무 환경을 확대시켜 나갈 필요가 있다. 이를 위해서는 학 교 현장에서의 다양한 임상실습 여건을 제공해 주는 것이 필요하 다. 예를 들어 미국의 SLP 경우 $55 \%$ 이상이 유치원부터 고등학교 환경에서 학교 SLP로 활동하고 있는 점을 감안할 때, 추후 국내에 서도 이러한 학교 환경에서의 임상실습이 주도적으로 이루어져야 할 것이다

최근 인구의 급감으로 인한 대학재정의 심각한 어려움과 급변하 는 대학 환경 속에서 언어재활 관련학과 또한 운영상의 어려움이 많다. 이는 임상실습 교육에 직접적인 영향을 초래하여 이상적으 로 실현해야 하는 임상실습 체계와 현실적인 체계 간의 갈등이 초 래될 수밖에 없기 때문에 언어치료 임상실습에 대한 명확한 지침이 나 공통된 가이드라인이 제시된다면 이를 바탕으로 양질의 언어재 활사를 양성하기 위한 최소한에 지켜야 할 요건이 마련될 수 있을 것이다.

결론적으로, 언어재활전문가로서 다양한 직무와 영역의 확장을 위해서는 언어재활사 양성교육기관인 대학에서 다양한 영역의 실 습이 이루어져야 하며, 학회나 협회의 교육을 통해 이에 대한 부가 적이고 전문적인 교육과 훈련이 병행되어야 할 것이다. 또한, 최소 한의 임상실습시간이 법적으로 규정되고 있지만, 다양한 의사소통 장애 영역에서 최소한의 기준에 대한 지침과 임상실습이 권고되는 것이 바람직하며, 이는 다양한 장애 영역의 언어재활사 배출과 취 업으로 이어질 것이다.

\section{REFERENCES}

American Speech, Language, \& Hearing Association. (2014). 2014 Standards and Implementation Procedures for the Certificate of Clinical Competence in Speech-Language Pathology. http://www.asha.org/Certification/2014Speech-Language-Pathology-Certification-Standards/.

Beukelman, D., \& Mirenda, P. (2005). Augmentative and alternative communication: supporting children and adults with complex communication needs (3rd ed.). Baltimore, MD: Paul H. Brookes.

Boswell, S. (2004). International agreement brings mutual recognition of certification. The ASHA Leader, 9, 1.

Hwang, H., Choi, S., Kim, S., \& Lee, M. (2012). Students' and graduates' satisfaction with clinical observation and clinical treatment practice in the Department of Speech \& Language Rehabilitation. A Collection of Learned Papers of Daegu Health College, 32, 211-220.

Kim, S. J., \& Lee, S. H. (2009). The development and evaluation of a clinical skill-based curriculum model for speech therapy. Korean Journal of Communication Disorders, 14, 413-428.

Kim, S. Y., \& Shin, M. S. (2015). A study of the satisfaction and teaching efficiency of clinical practice of students majoring in speech-language pathology. Journal of Speech-Language \& Hearing Disorders, 24, 17-31.

Kim, Y. T., Kim, J. O., Jeon, H. S., Choi, H. J., Kim, M. J., Kim, T. W., \& Kang, M. K. (2014). Job analysis of Korea speech-language pathologist using Delphi study. Journal of Speech-Language and Hearing Disorders, 23, 147161.

Koul, R. K., \& Lloyd, L. L. (1994). Survey of professional preparation in augmentative and alternative communication (AAC) in speech-language pathology and special education programs. American Journal of Speech-Language Pathology, 3, 13-22.

Kwon, S. B., Kim, S. J., Pae, S. Y., Yoon, H. R., Hwang, M. A., \& Shin, M. S. (2010). A basic study for department of speech pathology certification with a focus on the educational environment. Journal of Speech \& Hearing Disorders, 19, 1-23.

Lee, M. S., \& Park, H. (2016). A study of practical training anxiety, career decision-making self-efficacy, and carrier decision level of students majoring in language rehabilitation in college. Journal of the Korea Contents Association, 16, 169-179.

Lee, M. S., Park, H., \& Park, C. H. (2015). A study of the correlation between self-efficacy and practice-related anxiety of students majoring in speech rehabilitation. Journal of Speech-Language \& Hearing Disorders, 24, 147- 
158.

Lee, Y. K., Bae, S. Y., Gweon, Y. J., Kim, M. J., Park, K. J., Seo, K. H., ..., \& Pyo, H. Y. (2010). Clinical practice of speech-language therapy: theory and practice. Seoul: Hakjisa.

National Law Information Center. (2018). Enforcement of the Act on welfare of persons with disabilities. http://www.law.go.kr/lsInfoP.do?lsiSeq=199053 \&efYd=20171230\#AJAX.

Owens, R. E., Farinella, K. A., \& Metz, D. E. (2015). Introduction to communication disorders: a lifespan evidence-based perspective (5th ed., H. S. Lee et al., Trans.). Seoul: Sigmapress.

Pyo, H. Y. (2017a). A survey on clinical practicums in Graduate School Departments of Communication Disorders. Communication Sciences \& Disorders, $22,837-850$.

Pyo, H. Y. (2017b). A survey on clinical observation in graduate schools. Communication Sciences \& Disorders, 22, 421-433.

Yoon, J. H., \& Kim, J. W. (2013). A survey on the satisfaction and perception of the clinical practicum of students majoring in speech language pathology. Journal of Speech-Language \& Hearing Disorders, 23, 251-270. 
Appendix 1. The components of questionnaire

\begin{tabular}{|c|c|c|c|}
\hline 영역 & 하위 영역 & 문항 수 & 문항 내용 \\
\hline \multirow[t]{2}{*}{ 임상실습 교과과정 } & 교과과정 및 교과목 정보 & 5 & $\begin{array}{l}\text { 학점 } \\
\text { 시수 } \\
\text { 전공/교양 및 필수/선택 } \\
\text { 이론/실습 } \\
\text { 선수과목 여부 }\end{array}$ \\
\hline & 수강인원 및 교수진 정보 & 5 & $\begin{array}{l}\text { 담당교수 } 1 \text { 인당 수강인원 } \\
\text { 담당교수 전임/비전임 } \\
\text { 담당교수 자격증 유무 및 종류 } \\
\text { 닫당교수 임삭경력 } \\
\text { 담당교과의 평가 주체 }\end{array}$ \\
\hline \multirow[t]{6}{*}{ 임상실습 운영 } & 교내 기본 임상실습 & 10 & $\begin{array}{l}\text { 교내 임상실습지침서 여부 } \\
\text { 사전 교육(오리엔테이션) 여부 } \\
\text { 임상실습 서식지/기록지 여부 } \\
\text { 임상감독 지침서 여부 } \\
\text { 임상실습 감독 형태 } \\
\text { 직접/간접 감독 비율 } \\
\text { 임상실습 피드백/감독 주당 소요시간 } \\
\text { 보고서 관련 피드백 여부 } \\
\text { 프로그램 차원의 사례발표회 여부 } \\
\text { 강의평가/만족도 조사 여부 }\end{array}$ \\
\hline & 실습 장소, 영역 및 시간 & 4 & $\begin{array}{l}\text { 실습 장소(교내/교외) } \\
\text { 주요 실습영역 } \\
\text { 언어재환현장실무 내용 } \\
\text { 임상실습 시간의 적정성 }\end{array}$ \\
\hline & 심화/현장실습 & 3 & $\begin{array}{l}\text { 심화/현장 실습 여부 } \\
\text { 심화/현장 실습 의사소통장애영역 } \\
\text { 심화/현장 실습기관 }\end{array}$ \\
\hline & 임상실습비 운용 & 4 & $\begin{array}{l}\text { 교내 임상실습비 여부 } \\
\text { 교내 임상실습비 부담자 } \\
\text { 교외 임상실습비 여부 } \\
\text { 교외 임상실습비 부담자 }\end{array}$ \\
\hline & 임상실습 면제 & 3 & $\begin{array}{l}\text { 임상실습 면제 여부 } \\
\text { 임상실습 면제 과목 } \\
\text { 임상실습 면제 사유 }\end{array}$ \\
\hline & AAC 임상실습 & 5 & $\begin{array}{l}\text { AAC 실습 필요 여부 } \\
\text { AAC 실습 여건 } \\
\text { AAC 실습 여부 } \\
\text { AAC 실습 종류 } \\
\text { AAC 기자재 }\end{array}$ \\
\hline \multirow[t]{2}{*}{ 임상실습 환경 } & 실습실 & 12 & $\begin{array}{l}\text { 교내 실습실 여부 } \\
\text { 교내 실습실 전담 임상교수 여부 } \\
\text { 실습실 담당조교 여부 } \\
\text { 하ㄱㅛㅛ 기업 여부 } \\
\text { 실습실 면적(평) } \\
\text { 임상실습실 개수 } \\
\text { 임상실습실 형태 } \\
\text { One-way mirror 여부 } \\
\text { 임상실습 관찰실 여부 } \\
\text { 임상실습 관찰실 음향시설 여부 } \\
\text { 임상실습 준비실 여부 } \\
\text { 언어치료실 외 다른 치료실/검사실 유/무 }\end{array}$ \\
\hline & 검사도구 및 기자재 & 9 & $\begin{array}{l}\text { 언어발달장애 검사도구 여부 } \\
\text { 유창성장애 검사도구 여부 } \\
\text { 신경언어장애 검사도구 여부 } \\
\text { 조음음운장애 검사도구 여부 } \\
\text { 음성장애 검사도구 여부 } \\
\text { 삼킴장애 검사도구 여부 } \\
\text { AAC 여부 } \\
\text { 청각장애 검사도구 여부 } \\
\text { 기타 장비/기기 여부 }\end{array}$ \\
\hline 기타 & & 2 & $\begin{array}{l}\text { 임상실습 운영 시 어려운 점 } \\
\text { 임상실습 운영 개선을 위한 제언 }\end{array}$ \\
\hline
\end{tabular}

$\mathrm{AAC}=$ augmentative and alternative communication . 


\section{국문초록}

\section{언어치료전공 임상교과 및 임상실습의 국내 현황 조사}

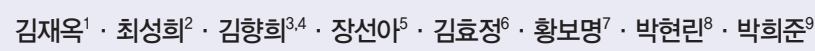

1강남대학교 교육대학원 언어치료교육전공, ${ }^{2}$ 대구가톨릭대학교 바이오메디대학 언어청각치료학과, ${ }^{3}$ 연세대학교 대학원 언어병리학협동과정, ${ }^{4}$ 연세대학교 의과대학 재활의학교실 및 재활의학연구소, ${ }^{5}$ 서울대학병원 이비인후과학교실, ${ }^{6}$ 고신대학교 보건복지대학 언어치료학과, ${ }^{7}$ 호남대학교 보건과학대학 언어치료학과, ${ }^{8}$ 광주대학교 보건복지교육대학 언어치료학과, ${ }^{9}$ 춘해보건대학 언어치료학과

배경 및 목적: 현재까지 국내 언어치료학과를 개설하고 있는 대학수는 총 50 개교이고, 교육과정 프로그램은 총 87 개까지 양적으로 증 가하고 성장하였으나, 국내 전반에 걸친 임상교육, 훈련 및 환경에 대한 정확한 정보는 아직 제공되지 않은 실정이다. 이에, 본 연구는 전 문적인 임상의 질적 기준을 마련하고자 국내 언어재활전공 프로그램을 운영하는 전문대학, 4년제 대학교 및 대학원을 대상으로 임상 교과와 임상실습 운영에 관한 현황을 파악하고자 수행되었다. 방법: 임상교과과정, 임상실습, 임상교육환경으로 설문을 구성하였으며, 국내 언어치료교육과정 프로그램 87 개 중 설문에 회신한 57 개(10개 전문대학, 19 개 4년제 대학교, 28 개 대학원) 과정들의 자료룰 분석 하였다. 결과: 비록 대부분의 프로그램들이 국가자격증을 취득하기 위한 핵심 임상 교과과정은 운영하고 있으나, 임상교과 학점, 시수, 훈련 내용과 실습 영역 및 임상환경은 다르게 나타났다. 대부분의 대학원 프로그램들은 언어치료전공자나 자격증을 보유하고 있는 학 생들에게 임상수업활동이나 임상실습을 면제하였다. 또한, 대부분의 프로그램들이 가장 많이 실습하는 주된 영역은 학령전기/학령기 언어발달장애 영역이었다. 모든 실습과목 담당 교수진이나 임상감독자들은 언어치료를 전공한 교원으로 언어재활사자격증을 가진 전 문가였으나, 세 개의 학제 간에 다양한 자격증 유형과 교수진의 형태를 보였다. 논의 및 결론: 언어치료학과 프로그램들 간의 일관된 질 적 임상 훈련이나 교육을 보장하기 위해서는 임상교육 훈련 내용이나 임상 환경에 관한 좀 더 구체화된 최소 표준 임상규준이 마련되어 야 할 것이다. 더 나아가 언어재활사의 전문성을 향상시키고 우리의 미래 의사소통장애 분야의 발전을 위해서는 다양한 임상교육과 훈 련이 제공되어야할 것이다.

핵심어: 임상실습, 임상교과, 언어치료 프로그램

본 논문은 한국언어재활사협회의 '인증사업단' 용역과제로 시행된 연구이며, 2017년 11월 4일 전국언어치료학과협의회 총회에서 일부 내용 이발표됨.

\section{참고문헌}

국가법령정보센터(2018). 장애인복지법 시행규칙. http://www.law.go.kr/lsInfoP.do?lsiSeq= 199053\&efYd= 20171230\#AJAX. 권순복, 김수진, 배소영, 윤혜련, 황민아, 신명선(2010). 언어치료학과 학과인증제를 위한 기초 연구. 언어치료연구, 19, 1-23. 김시영, 신명선(2015). 언어치료 전공학생의 임상실습만족도 및 교수효율성 연구. 언어치료연구, 24, 17-31.

김영태, 김재옥, 전희숙, 최현주, 김민정, 김태우, 강민경(2014). 델파이 조사를 통한 언어재활사직무분석 연구. 언어치료연구, 23, 147-161. 윤지혜, 김정완(2013). 언어치료 전공 학생들의 언어재활실습에 대한 만족도 및 인식. 언어치료연구, 22, 251-270.

이명순, 박현(2016). 전문대학교 언어재활과 학생들의 실습 불안과 진로 결정 자기 효능감 및 진로결정 수준 인식에 대한 연구. 한국콘텐츠학회논문

지, 16, 169-179.

이명순, 박현, 박찬희(2015). 언어재활과 학생들의 자기효능감과 실습불안에 대한 상관관계 연구. 언어치료연구, 24, 147-158.

이윤경, 배소영, 권유진, 김민정, 박혜진, 서경희, 윤효진, 이옥분, 이은주, 정경희, 정한진, 표화영(2010). 언어치료 임상실습: 이론과 실제. 서울: 학지사. 표화영(2017a). 언어치료프로그램 대학원 석사과정의 언어진단 및 언어재활실습 현황 연구. 언어청각장애연구, 22, 837-850.

표화영(2017b). 언어치료학과 대학원 석사과정의 언어재활관찰실습 현황 연구. 언어청각장애연구, 22, 421-433.

황화정, 최선영, 김시영, 이무영(2012). 언어재활과 재학생 및 졸업생들의 임상관찰 및 임상치료 실습에 대한만족도. 대구보건대학교 논문집, 32, 211-220.

Robert E. Owens, Kimberly A. Farinella, Dale Evan Metz (2015). 의사소통장애: 전 생애적 근거기반 조망(제5판, 김화수, 김성수, 이상경, 최성희, 최 철희 역). 서울: 시그마프레스. 